\title{
La centralidad del "reino de Dios" \\ en la teología de la liberación
}

\author{
Jon Sobrlno, \\ Ceniro de Reflexión Teológlca, \\ San Salvador, El Salvador.
}

\section{La teologla de la llberación como teología del "relno de Dlos"}

Toda verdadera renovación en la teologla proviene de contestar a la pregunla por lo que sea "úllimo" en la fe cristiana. Esto presupone que la fe cristiana eslá hecha de una diversidad de realidades que pueden ser organizadas y jerarquizadas. Que existe una jerarquia de verdades para la fe es una obviedad desde el Valicano II, pero el organizarlas y jerarquizarlas desde un principio último es cosa de la teologla. Esta debe buscar aquello último que mejor dé cuenta de la tolalidad de la fe, y según se delermine eso último asI será la teologla.

En nuestra opinión esto es lo que ha ocurrido en la leología desde hace un siglo con el redescubrimiento de que el mensaje de Jesús era escalológico. Sus descubridores propusieron un contenido concreto a lo escalológico: el reino de Dios; pero la imporlancia del descubrimiento fue más allá de la determinación del contenido. Para la teologla eslo significaba el fin del mero positivismo teológico, dogmático o bíblico, y el comienzo de teologías escatológicas; es decir, de teologlas que han tratado de nombrar lo último de la le y de desarrollarse desde ello - lerminando con el equivoco de adecuar escatologla con los novlsimos. El nombrar lo último ha supuesto la determinación de un eschaton desde lo especllico de la fe y de un primado de la realidad. Como eschaton pueden fungir la proclamación del kerygma de Jesucristo crucificado y resucitado (Bultmann), la comunicación a la historia del misterio santo (Rahner), el punto omega (Teilhard de Chardin); la resurrección universal (Pannenberg); a lo que corresponde un primado melafísicoantropológico diversamente entendido como el primado de la existencia y la decisión, el primado del tuturo, de la promesa y de la esperanza, el primado de la evolución, de la incondicional apertura al misterio, etc.

La teologla de la liberación se entronca lormalmente en esa forma de hacer comprender la leologla. Nombra algo último que puede fungir como principio organizador y jerarquizador de todo lo demás. Lo que sea el "primado" de esa leología le viene dado por su mismo nombre: la liberación; comprendida esen- 
cialmente como liberación de los pobres. En este sentido la teologla de la libera. ción es también una teologla escatológica, pues hace de la liberación no sólo un contenido de la teologla, por muy importante que ésta sea, sino un contenido último y jerarquizador. Por ello la leologla de la liberación no es teologla regional ni menos reduccionista. Al dar primado a la liberación de los pobres propone esle contenido como aquello desde lo cual se puede organizar el todo de la teologla: Dios y su Cristo, gracia y pecado, Iglesia y sociedad, amor y esperanza, etc. A la teologia de la liberación la llamamos escatológica no porque al añadir el adjetivo "integral" a la liberación se pueden aumentar cuantitativamente sus contenidos y convertirse en leologla tolalizante, sino porque desde la liberación de los pobres se piensa que es posible - y en América Latina necesario y conveniente- organizar cualitativa y jerarquizadamenle el todo de la teologla.

En esle arlículo queremos analizar qué realidad de la fe, qué eschaton corresponde más adecuadamenle a una leología que da el primado histórico a la liberación de los pobres. En otras palabras, como formular lo último de manera que se haga justicia a la revelación de Dios y a la histórica liberación de los pobres. En la elección de ese eschaton para la leologla -obviamente no se trata de elección para la te- se ofrecen dos posibilidades que hoy son tenidas muy en cuenta por las teologías creativas y que en principio serian también aptas para incorporar el esencial interés liberador de la leologla de la liberación. Estas dos posibilidades son "la resurrección de Cristo" (entendida como ínicio de la resurrección "universal") y "el reino de Dios." Ambas realidades son escatológicas desde una comprensión bíblica y sistemática y ambas expresan en sl mismas liberación. Por ello son usadas en varias teologlas modernas, aunque unas se inclinan por una posibilidad y otras por otra.

Por recordar algunos ejemplos importantes, Bultmann se inclina exclusivamente por la resurrección, más exactamente por la predicación del kerygma de Jesucristo crucilicado y resucitado, como el verdadero acontecimiento escatológico, con la triple connotación de ser juicio, salvación y presencia de lo último en la historia. El reino de Dios no es considerado por perlenecer, como todo lo del Jesús histórico, a los presupuestos, no a la teologla del NT. Pannenberg valora más el reino de Dios como lo escatológico, pues el anuncio de su venida -cercana, aunque no realizada- posibilita y exige que ya en la hisloria se viva en radical apertura y se realice asl lo último. Sin embargo, el acontecimiento escatológico definitivo, también para la teologla, es la resurección de Jesús, pues en ella se ha cumplido, aunque provisionalmente, el objeto de la apertura del hombre y la revelación de Dios. Moltmann se orientó en sus comienzos desde la resurrección y su correlativa esperanza, pero cada vez más ha ido formulando el eschaton también desde lo histórico, desde los pobres, desde su liberación y. asl, desde el reino de Dios.

Estos recordatorios sólo pretenden poner un maroo donde se entienda mejor la respuesla que da la leologia de la liberación a la pregunta por el eschaton. Para esa teología lo que funge como lo úllimo es el reino de Dios. No significa eslo, por supuesto, que ignore la resurrección, ni que no vea su dimensión claramente escatológica; pero para hacer una teologia que da primado a la liberación de los pobres ve mejor expresado el eschaton como reino de Dios.

Esta primacla del reino de Dios no se deduce de tal o cual alirmación explicita, aunque las hay, sino del quehacer concreto de la teologla de la 
liberación, de aquello por lo que muestra más interés y analiza más en delalle, de aquello que relaciona más frecuentemente con lo que es su primado: la liberación de los pobres. Ya en los comienzos, en el clásico libro de G. Gutiérrez Teologla de la liberación, ${ }^{1}$ se revaloriza claramente el enfoque escalológico de la teologla (pp. 201-215), pero al servicio de su problema mayor, la liberación y la salvación histórica (pp. 183-200). Y se concluye con el rejno de Dios como la realidad más adecuada para expresar la liberación, aunque en este libro el tratamiento del reino no se hace desde un punto de vista bíblico, sino desde el magisterio de la lglesia (pp. $216-229$ ). Desde entonces no se puede negar que en las cristologlas ${ }^{2} y$ las eclesiologlas ${ }^{3}$ de la teología de la liberación se ha dado gran importancia al reino de Dios y se ha hecho de ál in actu lo central y lo último o, al menos, algo más central y más último teológicamente que olras cosas. I. Ellacuría ha explicitado esa centralidad del reino de Dios en la teologla de la liberación alirmando que ésie es "el objeto mismo de la teologla, de la moral y de la pastoral cristianas: la mayor realización posible del reino de Dios en la historia es lo que deben perseguir los verdaderos seguidores de Jesús. ${ }^{-4}$

Si el hecho nos parece claro, más importante es analizar por qué la teologla de la liberación da prelerencia al reino de Dios como el eschaton. Variadas son las razones y trataremos de resumir las más importantes.

La teologla de la liberación en su propio quehacer tiene un determinado talante que no se puede negar, cualesquiera hayan sido sus acierlos y limitaciones. En ello no se diferencia totalmente de otras teologlas, pero sí recalca algunas dimensiones del quehacer teológico que le son más específicas a ella que a las otras.

La teologla de la liberación es claramente una teologla histórica que busca historizar y verificar en la historia todos los contenidos de la fe y también los estrictamente transcendentes. Su propio nombre no es más que la historización de lo central de la fe cristiana: la salvación como liberación. Es también una teologla profética que tiene en cuenta como algo cenlral el pecado y el pecado histórico, como aquello que hay que desenmascarar y denunciar. Es una teologia práxica que se comprende a si misma como momento ideológico de una praxis eclesial e histórica; es decir, que está interesada anles que nada en transiormar la realidad, aunque defienda su stalus teológico y crea que a través de ello se pueda ayudar a la transiormación de la historia. Es una teología por úllimo popular -aunque haya diversas comprensiones de ello- que ve en el pueblo, en su doble connotación de pobreza y colectividad, el destinalario y, en algunas teologlas, aunque analógicamente, incluso el sujeto de la misma.

Siendo esto asi no es de extrańar que la teologla de la liberación encuentre espontáneamente en el reino de Dios una realidad más apla que otras para desarrollar su propio talante y guiar su propio quehacer. Veamos, ya que no se puede obviar la cuestión, por qué la teologla de la liberación no hace de la resurrección, el otro símbolo del eschaton, aquello que mejor puede organizar el todo de la teologla.

La resurrección de Jesús, entendida como primicia de la resurrección universal, ofrece sin duda imporlantes elementos para fungir como lo último: la ple- 
nilicación y salvación absolutas y, asl, la liberación absoluta, la liberación de la muerte; la radical esperanza que exige y desencadena, más allá y contra la muerte, la ultimidad y universalidad de la revelación de Dios. La resurrección puede también ser interpretada $-y$ no necesariamente en base a una arbilraria interpretación, sino en base a los texlos bíblicos- de tal manera que recoja $\theta$ ilumine importantes elemenlos que interesan a la teología de la liberación. Puede asl decirse que la resurrección de Cristo no es sólo revelación del poder de Dios sobre la nada, sino el triunfo de la juslicia; que la resurrección ofrece en directo no una esperanza universal, sino una esperanza parcial -aunque después pueda ser universalizada - para las victimas de este mundo, a los crucificados —como Jesús- de la historia; que la resurrección puede desencadenar una esperanza absolutamente radical para la historia, pues si Dios se muestra con poder para liberar de la muerte, mayor poder tendrá para liberar de la opresión; que la resurrección no es sólo un símbolo de esperanza personal-individual, sino también de una esperanza colectiva, pues la resurrección de Jesús es presentada en su misma entraña como resurrección del primogénilo, a la que debe suceder _-para que el mismo concepto tenga lógica interna- la resurrección de olros muchos; que la resurrección asume y da la debida importancia - a diferencia de otras expresiones de la esperanza de supervivencia, como la del pensamiento griegoa lo material-corṕrreo, pues todo el ser humano es el que resucita y queda asumido en la plenitud; que incluso la resurrección puede ser ya vivida en la historia, historizada por lo tanto, al dejar sentir su fuerza especlfica en una determinada manera de vivir el seguimienlo de Jesús en gozo y libertad -realidades ambas que rellejan en la historia limilada lo plenificante de la resurrección.

Todo esto es verdad, es desarrollado en varias teologlas y es valorado por la teologla de la liberación. 5 Pero, con todo, es evidente que para que la resurrección pueda fungir como lo último para una teologla con el talante descrito hay que hacer un inmenso esfuerzo de interprelación. Dicho de otra forma, la resurrección puede interpretarse de tal manera que pueda fungir como lo último para la teología de la liberación; pero esa interpretación tiene menos apoyaduras obvias en la realidad histórica, tal como ésta es caplada en su primariedad. La resurrección, que en sl misma liene gran fuerza para expresar el sentido úlimo de la historia y la esperanza radical, no tiene tanta fuerza para mostrar cómo haya que vivir en la historia. Tiene gran fuerza para mostrar la utopla tinal, pero no tanta para mostrar cómo haya que vivir ya ahora y encaminarse hacia esa utopla. La resurrección —como cualquier otro slmbolo de plenilud que se elija, incluido el del reino de Dios- ofrece también, no en el concepto, pues en él se puede superar, pero sl en la vida real su propia peligrosidad. No debieran asustar estas palabras, pues cualquier cosa que tocamos los seres humanos por buenas y santas que sean - sea la oración o la lucha por la justicia- queda somelida a nuesira limitación y concupiscencia. No se puede negar, pues lo alirma repetidamente la historia, que una orientación leológica unilateral hacia la resurección puede y suele fomentar un individualismo sin pueblo, una esperanza sin praxis, un entusiasmo sin seguimiento de Jesús; en suma, una Iranscendencia sin historia. Desde los entusiasmos de la comunidad de Corinto hasta los entusiasmos actuales, católicos, protestantes y sectarios, la historia lo muestra abundantemente. La teologla de la liberación es por su propio talante especialmente sensible a este peligro. 
Todo lo dicho sobre la resurrección hay que entenderb bien. No se dice, por supuesto, que la resurrección de Cristo, primicia de la resurrección universal, no sea una realidad y una realidad central para la fe y para la teologla; no se dice que en la leologla de la liberación no se le dé la debida importancia a la resurección, pues es tratada debidamente en las cristologlas y es tenida en cuenta en la formulación de la utopla cristiana. No se ignora que en la resurrección aparecen mejor y más radicalmente expresados, mejor incluso que en "el reino de Dios," algunos aspectos de la fe: la radicalidad de la utopla, la definitiva manifestación de Dios, la gratuidad última. No se niega que la resurrección pueda fungir como antidoto contra una concepción puramenle dolorista y resignada de la cruz, a la que lenderla una religiosidad popular tradicional; ni que, por otra parte, no sea útil para criticar utoplas no consecuentemente radicales. P. Miranda llega a decir que Marx no tuvo la suficiente dialéctica para llegar a concebir una translormación del mundo que incluyera "la resurrección de los muertos. 6 Lo único que se quiere decir es que para la teologla de la liberación la resurrección no es visla como realidad tan apta como la del reino de Dios para fungir como lo último, para organizar y jerarquizar teológicamente el todo de la le. La resurrección es muy tenida en cuenta, pero dentro de algo más abarcador que es el reino de Dios.

Además de que el reino de Dios corresponde mejor al lalante de la leología de la liberación, se ve en él una mayor capacidad de organizar sistemáticamente el todo de la teologla, tal como ésta debe llevarse a cabo en una realidad como la del tercer mundo. I. Ellacurla, quien insiste en hacer del reino de Dios el objeto de la teologla, lo ejemplifica de la siguiente manera. Aunque la cita es algo larga la ofrecemos para ahorrarnos largos comentarios.

Esta concepción de la le desde el reino de Dios lo que hace es poner en conjunción indisoluble a Dios con la historia... El reino de Dios evade toda una serie de desviaciones peligrosas. Supera el dualismo reino (terrestre) y Dios (celestial), de modo que los que cultivan el mundo y la historia estarlan haciendo algo meramente positivista mientras que los que se dedican a Dios estarian haciendo algo transcendente, espiritual y sobrenatural. No acepta que el reino de Dios se identitique con la Iglesia y, menos aún, con lo institucional de la kglesia, lo cual supondrla por un lado la evasión del mundo al interior de la Iglesia y por otro un empobrecimiento del mensaje y de la misión cristianas que acaban mundanizando y secularizando la Iglesia al conformarla en su instilucionalidad $\infty$ nalores secularistas de dominación y riqueza y sometiendo a ella lo que es mucho mayor que ella, el reino de Dios. No deja que se manipule el nombre y la realidad de Dios en vano porque comprueba su invocación en los signos históricos de justicia, fralernidad, libertad, opción prelerencial por los pobres, amor, misericordia, etc., sin los cuales no se puede hablar de presencia salvifica de Dios en la historia.

El reino de Dios como reinado de Dios entre los hombres pone de manifiesto la malicia histórica del mundo y con ella el reino del pecado, la nega- 
ción del reino de Dios. Además de un cierto pecado natural (original) y de un pecado personal (individual), el anuncio del reino y la dificultad de implantarlo hacen presente un pecado del mundo, que es fundamentalmente histórico y estructural, comunitario y objetivo, truto a la vez y causa de otros muchos pecados personales y colectivos y que él mismo se propaga y se consolida como la negación permanente del reino de Dios. No es que las estructuras pequen, como algunos les hacen decir a los té́logos de la liberación, pero las estructuras manifiestan y actualizan el poder del pe. cado y en ese sentido hacen pecar y dificultan sobremanera el que los hombres lleven la vida que les corresponde como hijos de Dios. Ese poder pecaminoso es absolutamente real, es en sí pecado y fruto del pecado -recuérdense las explicaciones tradicionales del pecado originat, pero además hace pecar al obslaculizar el dinamismo del reino de Dios entre los hombres, la presencia del Esplritu vivificante entre las potestades y los poderes de la muerte. Recobra asl el mal del mundo una dimensión transcendente sin separarse de la inmanencia que le es propia... La destrucción de la vida humana o su empobrecimiento no es ni tan siquiera un problema puramente moral sino que es también y sin fisuras o diferenciaciones un problema teológico, el problema del pecado puesio en acción y el problema de la vida negada en la existencia humana. ${ }^{7}$

En esta larga cita se puede apreciar que la primacla que se da al reino de Dios reside en su capacidad de unificar, sin separación ni confusión, transcendencia e historia, superando peligrosos dualismos y ofreciendo una veríticación a la realización de to transcendente en la historia. Desde ahi pueden y deben comprenderse contenidos esenciales, como Crislo y la lglesia, sin el peligro de abstracciones idealistas o de suplantación espúrea del reino por lo que no lo es. Además, aunque no se use esta terminología en la cila, el reino de Dios es lo que hace redescubrir el anlirreino, el mundo de pecado; $y$, de nuevo, unificadamenle: como mal histórico y transcendente. La dualidad última en la realidad, en cuanto dualidad irreconciliable, no aparece tanto en el binomio transcendencia e historia -que pueden y debe ser reconciliadas-, sino en el binomio irreconciliable de reino y antirreino, historia de gracia y de pecado.

El reino de Dios, comprendido con esa radicalidad, ofrece a la teologla de la liberación dos cosas a las que no puede renunciar. La primera es una totalidad, necesaria para que la teologla de la liberación sea simplemente teologla. La segunda es una determinada hislorización de esa totalidad, necesaria para que la teologla pueda ser teologla de la liberación. Las diferentes tensiones que aparecen en cualquier teología que quiere ser fiel a la totalidad del mensaje están planteadas en la realidad del reino de Dios, pero resueltas de tal manera que se mantiene y aun potencia lo más específico de la teologla de la liberación. El reino de Dios implica transcendencia e historia, salvación y liberación, esperanza y práctica, lo personal y lo comunitario-popular. Los elementos que aparecen en la segunda parte de las tensiones son los más especfficos - por novedosos, no por excluyentes de los otros- de la teologla de la liberación. El reino de Dios olrece entonces la posibilidad de tomar seriamente en cuenta los aspectos más novedosos de la teologla de la liberación y de elaborarlos dentro de la totalidad de la le. 
Con ello se mantiene la especificidad de la teología de la liberación y su idenlidad cristiana. Vista la liberación desde el reino de Dios se hace justicia a la intuición original de la teologla de la liberación y se enmarca a ésta en una totalidad que por su naturaleza lleva a plantear la plenitud de la liberación - "liberación inlegral" se la llama en Jenguaje ortodoxo, aunque poco dicente- sin que eslo quite radicalidad a la intuición original.

El talante y deseo sistematizador de la teologla de la liberación explica por qué tiene primacla el reino de Dios. Pero existe todavla una razón más primigenia. La teologla es siempre un acto segundo en y ante una realidad y la teología de la liberación lo recalca explícitamente. Pues bien, es la realidad latinoamericana y en general la del tercer mundo la que clama por un reino de Dios, sea como luere el modo de formularlo. El hecho mayor en América Latina es la masiva $\theta$ injusta pobreza que acerca a la muerte a las mayorlas. Por otra parte el hecho más novedoso es la esperanza de vida justa, de liberación. Esá realidad es la que exige ser reflexionada y ante la que hay que reaccionar con primariedad y, Iogicamente, con anterioridad a cualquier reflexión teológica e incluso a cualquier determinada fo. Es la misma realidad la que exige ser visla como realidad de vida o de muerle, la que hace la pregunta por la esperanza o por la desesperación, la que exige una opción en favor de la vida o de la muerte. La captación de la realidad primaria como pobreza injusta y esperanza de vida justa, y como exigencia a apostar en favor de la vida puede después ser reformulada en la reflexión teológica como precomprensión necesaria para entender la revelación de manera adecuada, y puede ser teologizada como signo de los tiempos y manifestación de la voluntad divina. Todo ello es verdad y lo hace la leología de la liberación. Pero en sI mismo es algo más primigenio; es la captación de una realidad que en sí misma posee su propio clamor.

Pues bien, cuando la teologla ve la realidad latinoamericana en ese primer momento pre-leológico encuentra, sin caer en ingenuidades ni anacronismos, una realidad que liene gran alinidad con la realidad en que surgí la noción de reino de Dios, tanto bíblicamente en ese lenguaje como extrabíblicamenle en otros. Es verdad hoy que existen pueblos enleros injustamente oprimidos y que tienen esperanza de vida; es verdad hoy que ése es el hecho mayor desde el cual se comprende mejor la lotalidad y las diversas dimensiones élicas, práxicas y de sentido que emergen de ella. Si eso es verdad y si esto está en afinidad histórica con la realidad en que cuajó la formulación de la utopla como reino de Dios, es entonces bastante obvio que la teologización de la realidad del tercer mundo se haga usando la teologla del reino de Dios. La realidad histórica actual es la que hace en último término que el reino de Dios sea hoy más útil que otros conceptos para elaborarla teológicamente. La alinidad entre ambas realidades, la actual del tercer mundo y la de los pueblos que lorjaron el "reino de Dios," es también lo que posibilita comprender mejor lo que entonces significó el reino de Dios. El Horizontsverschmelzung (entrelazamiento de horizontes) que exige la hermenéutica se realiza antes que nada en la misma realidad.

Lo que ha ocurrido entonces en la teología de la liberación es que en un momento pre-teológico se ha captado la realidad como irrupción del pobre con una esperanza de liberación. Esa captación supone un pre-juicio, si se quiere; pero en ello eslá el origen de la teologla de la liberación. Cuando ésta se conslituye 
formalmente en leologla desde el primado del pobre o, más exactamenle, de la liberación del pobre, se enrumba según la teologización que de eso mismo se hizo hace muchos siglos en la AT y en Jesús: el reino de Dios. La situación hislórica es la que en último término fuerza a esa elección. En otros lugares donde la teología no ha podido descubrir la irrupción del pobre $\longrightarrow$ por pasar ésta más desapercibida o por no tener interés en descubrirla- no se ha enrumbado hacia el reino de Dios, sino hacia la resurrección. En América Latina y en el tercer mundo en general, sin embargo, la actual y previsible situación histórica sigue forzando a la leologla a enrumbarse según el reino de Dios. La misma realidad latinoamericana clama con urgencia por la venida del reino de Dios. Puede manlenerse la esperanza última de una resurrección universal, pero la urgencia del clamor se dirige al advenimienlo del reino de Dios. Y aquí eslá, en definiliva, -además de en el urgenle recordalorio ante el olvido té́rico que parece darse en la lglesia- la razón y finalidad de volver al lema en este artículo. El tercer mundo sigue necesitando urgentemente de liberación y el mejor tratamiento teológico de ésta sigue haciéndose desde el reino de Dios.

\section{La determinación del relno de Dlos en el evangello}

Que el reino de Dios sea algo cenlral en la teologla de la liberación nada dice todavía de lo que es ese reino. Su determinación actual - lo que abordaremos en el siguiente apartado- no es cosa tácil. Pero ni siquiera lo es su determinación evangélica. Y ello por una razón obvia: Jesús, que tantas veces usa la expresión, que tanto intenta esclarecerlo en sus parábolas, nunca dice con exaclitud qué es ese reino: "Jamás nos dice Jesús expresamente qué es ese reino de Dios. Lo único que dice es que está cerca, ${ }^{n \theta}$ afirma Kasper con razón.

De ahl no se deduce, por supuesto, que nada puede saberse de lo que el reino de Dios signílicó para Jesús. Lo que sl se deduce es la necesidad de un método o, digámoslo más modestamente, de una vía para averiguarlo. En nuestra opinión las cristologias sistemáticas, cuando abordan el terna del reino de Dios bíblicamente, usan varias vias, la vla nocional, la via de la práctica de Jesús y la vla del destinalario del reino. Estas vlas no son excluyentes sino complemenlarias; pero según se use una u otra, según se haga más énfasis en una o en otra, asl será la noción que se desprende del reino de Dios. El aporle de la teologla de la liberación a la delerminación del reino de Dios no consisle especialmente en descubrimientos exegéticos. Consiste más bien en insistir en la limitación y peligrosidad de considerar sólo la primera via, y en recalcar la necesidad de la segunda y especialmente de la tercera. Eso lo muestra la teologla de la liberación en su propio quehacer cuando analiza el anuncio del reino de Dios hecho por Jesús. Lo que haremos a continuación es analizar por separado cada una de las vlas, insistiendo en aquellos aspectos donde más especlficamente insiste la teologla de la liberación. Su aporte más especlfico está, entonces, en el método para llegar a delerminar lo que es el reino de Dios.

La vla nocional intenta averiguar lo que fue el reino de Dios para Jesús a partir de la noción que el mismo Jesús pudo tener de él. Se analizan asl las diversas nociones del reino en el AT y en los conlemporáneos de Jesús (Juan 
Baulista, zelolas, fariseos, grupos apocalípticos, elc.), se indaga en to que Jesús recogió de ellas y en lo que se diferenció, y se construye de esla forma lo que Jesús pensó del reino. El resumen de estas investigaciones -expresado en lérminos formales- suele ser el siguiente: Jesús anunció una utopla, algo bueno y salvilico, que se acerca. ,

Esto es verdad y lo asume la teologla de la liberación. L. Bolf, por ejemplo, dice bellamente que al anunciar la venida del reino -Jesús articula un dato radical de la existencia humana, su principio esperanza y su dimensión utópica. $Y$ promete que ya no será utopla, objeto de ansiosa expectación (ctr. Lc. 3,14), sino topla, objeto de alegría para todo el pueblo (ctr. Lc. 2,9).9 El problema está en $\infty$ mo se concreta un poco más esa noción de reino de Dios, y en ello se nota la importancia que se le da o no a las otras dos vias. Cuando éstas no están activamente presentes en la investigación -decimos activamente porque de algún modo siempre están presentes - la noción del reino suele quedar en suma vaguedad y abstracción. Esto no quita que lo que se diga del reino no sea algo verdadero, bueno y santo, algo -digámoslo asi- con lo que Jesús también eslaría de acuerdo. Pero esa vaguedad y abstracción no ayudan para saber lo que en concrelo tue el reino para Jesús y pueden ser peligrosas cuando hacen pasar a segundo plano o simplemente ignorar cosas importantes que Jesús quiso decir con el reino de Dios. Veamos dos ejemplos.

Kasper analiza en su crislología 10 el reino de Dios (p. 86-107) como el mensaje central de Jesús, su carácter escatólogico y teo-lógico. Cuando quiere decirnos qué es en definiliva ese reino se fija muy brevemente en su destinatario según los evangelios (p. 103s) y en algunas obras de Jesús (p. 105) para concluir - Cormalmente- que el reino de Dios es salvación. Cuando se espera alguna concreción de lo que sea esa salvación Kasper responde de la siguiente manera. "En consecuencia podemos decir: la salvación del reino de Dios consiste en que llega a imperar en el hombre y por el hombre el amor de Dios que se aulocomunica. El amor se manifiesta como el sentido del ser. Unicamente en el amor encuentran plenitud mundo y hombre" (p. 106). La respuesta a lo que es el reino es aqul sistemálica, pero se supone que recoge el análisis que se ha hecho de los evangelios: "en consecuencia," comienza el párralo. Si ésta es la realidad objetiva del reino - al anor-, lo que añade el anuncio de su cercania es lo siguiente: "cada individuo puede esperar que el amor sea lo último y lo definitivo, que sea más fuerte que la muerte, que el odio y la injuslicia. El mensaje de la llegada del señorío de Dios representa, pues, una promesa para lodo lo que se hace pasar por amor en el mundo: lo que se hace por amor lendrá consislencia para siempre contra toda apariencia, aún más, es lo único que existe para siempre" (p. 106).

Amor, esperanza, promesa, son realidades sumamente importantes y centrales en los evangelios y en todo el NT, son también realidades que tienen que ver con el reino de Dios predicado por Jesús. Lo que desconcierta y decepciona es que se presenten $\longrightarrow$ y en ese grado de abstraccion-como resultado de una investigación sobre lo que es el reino de Dios y el signticado de su cercanla en los evangelios. Lo que aqul se dice ser el reino de Dios pudiera ser dicho también a propósito de la resurrección de Jesús o de la primera carta de Juan o del himno de la caridad (1Cor. 13) o del himno de la esperanza (Rom.8, 31-39). No que lo que se dice sea lalso en sI mismo, sino que no se ve cómo ello esclarece el 
contenido concrelo del reino de Dios predicado por Jesús, y se intuye más bien que oculta algo muy importante de ese reino. De esa forma el reino de Dios pierde no sólo concreción sino centralidad y se hace práclicamente intercambiable con otras realidades del NT.

El segundo ejemplo está tomado de la cristologla de Pannenbertg. ${ }^{11}$ Esta recalca la imporlancia del reino de Dios predicado por Jesús. Su cercanla es salvación, implicada en el término "Padren" con que Jesús habla del Dios que se acerca (p. 284), lo cual exige y posibilita una vida en el amor (p. 280ss). Pero si se pregunta qué es la salvación del reino y por qué su cercanla puede ser salvación, Pannenberg responde con la siguiente solución, que en si misma nos parece muy original y hasta genial, pero muy poco iluminadora a la postre.

Al anunciar Jesús la venida próxima del reino el hombre se ve obligado a "salir de sus seguridades cotidianas," a "superar cualquier cumplimiento de la existencia y cualquier seguridad actualmente real o posible" (p. 281). En cuanlo el Dios que viene es todavia futuro, el anuncio de su venida maniliesta "la apertura de la exislencia a Dios" (p. 281). En una palabra, ante el reino de Dios que viene el hombre se descubre como lo que verdaderamente es, como el ser abierto por esencia y radicalmente a Dios, sin adecuar nada de lo que es con lo definitivo. Pero precisamente, esa incondicional apertura que posibilita y exige el anuncio de la venida del reino, es salvación para el hombre. "Dado que la salvación consiste en el cumplimienlo de la determinación especillica del hombre, en la plenitud de la apertura hacia Dios, por eslo ya es algo actual para aquellos que anhelaban la proximidad de Dios predicada por Jesús" (p. 283).

La argumentación de Pannenberg es aqui lormal. Desde su propia antropologia12 puede ver salvación en el hecho de que el reino, cercano pero no realizado, exige y posibilita la radical apertura del hombre, el vivir radicalmente de la conlianza. "En el lenguaje moderno cabe decir que Jesús pone al hombre en la apertura radical que constituye el rasgo especlifico fundamental del ser humano" (p. 287). Pero esta argumentación tormal la ve exigida y justificada en lo concreto de la actuación de Jesús: "sus curaciones ponen de maniliesto de un modo inmediato que alli donde se acepta por entero y con entera confianza el mensaje sobre la proximidad de Dios la salvación en cuanto tal es ya electiva" (p. 283s).

El reino de Dios es salvación, por lo tanto, porque al estar llegando, sin llegar nunca en plenitud, permite vivir realmente como verdaderos seres humanos. De aht deduce Pannenberg que, una vez llegado el hombre a su propia esencia, lenga que actuar como actúa el mismo Dios: en el amor (pp. 288s).

Esta solución de Pannenberg tiene en cuenta la esperanza, el amor y la salvación; es además una genial inlerpretación del clásico "ya pero todavla no" de Cullmann. Pero la noción de reino de Dios queda, de nuevo, genérica por universalizada y pasa por alto cosas sumamente importantes del reino de Dios.

Estos dos ejemplos muesiran que lo que hemos llamado la vla nocional, prácticamente aislada, tiene graves limitaciones y peligros. Se pretende subsumir el reino de Dios en un concepto que, en el fondo, corresponda a lo que previamente se haya decidido ser el reino de Dios. Este peligro es siempre, en parle, inevilable y no se puede superar del todo. Pero lo que ayuda a concretar la precipitada universalización del concepto del reino de Dios y a superar el que sea el propio interés el que gule su determinación está en la consideración de las otras dos vias. 
La vla de la praxis de Jesús dice que la que sea el reino se iluminará también desde lo que hizo Jesús. Asl lo afirma Schillebeeckx. "El contenido concrelo del rieno surge de su ministerio y actividad consideradas como un todo." 13 Esta opción metodológica está claramente justíficada por lo que toca a aquellas actividades de Jesús que él mismo relacionó con el reino, explicitamente (expulsión de demonios, predicación en parábolas) o implicitamente (las comidas). Pero la opción es también razonable para toda la actividad de Jesús; ciertamenle para la gran primera parte de su vida, si en verdad el anuncio del reino fue lo central para él.

Para esclarecer la importancia de este punto hay que recalcar en primer lugar el hecho mismo de la práclica de Jesús, lo cual en pura lógica no tendrla por qué haber sido así. Hagámonos las siguientes preguntas lógicas e hipoláticas. Si Jesús pensó que el rieno de Dios llegaba pronlo y gratuitamente, ¿por qué no reducirse a su anuncio, por qué no esperar contiada y pasivamente esa venida, por qué no aceptar la situación de su mundo si pronto iba a cambiar? En otras palabras, ¿a qué la práctica de Jesús? Estas pregunlas puramente lógicas sólo tienen una respuesta histórica. Jesús hizo muchas cosas. En pura lógica de nuevo, puede preguntarse si las hizo porque el reino ya se hacla presente o para que se hiciese presente; es decir, si las obras de Jesús eran puramenle sacramentales como expresión de un reino que se acerca graluitamente o eran también servicio al reino para que se acerque. Sea cual fuere la respuesta a estas preguntas, lo importanle es recalcar que Jesús hizo muchas cosas y no esperó pasivamente la venida del reino (ni exigió esa actitud a sus oyentes). Ni siquiera en el corlo plazo de espera de la proximidad del fin pudo Jesús tolerar la situación de su mundo, como dice Culmann. ${ }^{14}$

La actividad de Jesús al servicio del reino es comprensible a priori, pues ya según Isalas (y en la concepción de Lucas) el anuncio de la buena noticia, el contenido del reino, va por esencia acompañado de un hacer. "Solo será buena esa noticia en la medida en que se realice la liberación de los oprimidos. ${ }^{-15}$ Pero no sólo a priori. Junlo al sumario programático del anuncio del reino, aparecen desde el principio los sumarios de su actividad: "Jesús recorrí́ loda Galilea predicando en sus sinagogas y expulsando demonios" (Mc. 1,39). "Jesús curó a muchos que adolecian de diversas entermedades y expulsó a muchos demonios" (Mc. 1,34 y par). En el sumario de Hechos 10,38 se dice que "pasó haciendo el bien y curando a todos los oprimidos por el Diablo."

El hecho de la actividad de Jesús es claro; el relacionarla con el reino de Dios está justiticado evangélicamente en muchos casos y es razonable sistemáticamente. Lo importante enlonces es ver lo que aporla su actividad a la determinación del reino -y que concrele las vaguedades de su formulación. Analizaremos brevemente tres estadios de su actividad, diciendo desde el principio que sólo por razones metodológicas separamos esta vla de la tercera, la vla del destinatario.

Jesús realizó una serie de actividades como "signos" del reino. En cuanlo signos no son la totalidad del reino; pero si lo presentizan, algo se podrá conocer de él a partir de aquéllos. Signos del reino son los milagros, la expulsión de demonios, la acogida a los pecadores; y signos de la celebración del reino son las comidas. Concentrémonos, por no alargar el análisis, en los milagros. 
Formalmente los milagros son signos de que el reino de Dios se acerca con poder, "clamores del reino," como se les ha llamado. No son por lo tanto el reino en totalidad ni presentan una solución totalizante a los males que el reino debe remediar. En cuanto signos del reino los milagros son ante todo salvación, realidades benélicas y realidades liberadoras en presencia de la opresión. De ahl que los milagros generan gozo por lo benéfico y generan esperanza por lo liberador.

¿En qué ayudan los milagros para comprender el reino de Dios si son sólo signos? Fundamentalmente porque alirman que el reino de Dios es "salvación," pero con dos precisiones importantes que la concretizan. La primera es que la salvación es concreta y por ello plural. En los milagros aparece que Dios salva de necesidades reales, inmediatas, sin determinar de antemano de qué necesidades vaya a salvar el reino. Esto es importante recalcarlo porque después de la resurección -como ocurre con otras cosas del Jesús histórico, tampoco sus milagros son muy mencionados en los escrilos del NT con la excepción de los evangelios - la salvación se convierte en término técnico, totalizante y en singular: Cristo trae la salvación. Pero en los sinópticos la salvación no aparece de esta forma. No hay salvación, sino salvaciones, superación de males concretos. "Asl, salvar es curar, exorcizar, perdonar por medio de acciones que alectan al cuerpo y a la vida, ${ }^{16} \mathrm{De}$ ahl que los milagros, precisamenle por su concreción y "pequeñez," en comparación con la grandiosidad con que se esperaba que viniese el reino, no fuesen comprendidos por todos; no por los grupos apacallpticos que esperaban prodigios portentosos como señales de la venida del reino, pero si por aquellos que necesitaban "salvaciones" en su vida cotidiana. Por eso dice bellamente Schillebeeckx que "en la tradición de los milagros nos encontramos, pues, con un recuerdo de Jesús de Nazarel basado en la impresión que causo particularmente en el pueblo rural de Galilea, que era menospreciado por todos los movimientos y grupos religiosos." ${ }^{-17}$

La segunda es que los milagros no son sólo salvación, sino estricta liberación. Las concretas necesidades de las que hay que salvar son producto de algún tipo de opresión. Las entermedades $-y$ mucho más radicalmente aparece eso en las posesiones del demonio- eran comprendidas como produclo del poder opresor del Maligno, según las concepciones demonológicas que permeaban la mentalidad de la época. "Reinaba un terror intenso a los demonios," dice J. Jeremias. En el caso de la acogida a los pecadores no se trataba sólo de aceplar bondadosamente su compañla, sino de acoger a los rechazados por la sociedad religiosa, a los oprimidos por la religiosidad vigente. Los milagros, y los signos de Jesús en general, no ocurren sólo como satisfacción de necesidades desde una tabula rasa, sino en una situación de opresión, en una siluación de antirreino. Por ello no son sólo signos de salvación, sino de liberación; no son sólo salvaciones de necesidades concretas, sino liberaciones concretas.

Los milagros (y la acogida a los pecadores) esclarecen también algo muy importante, que se explicitará mejor al hablar del deslinatario: la razón por la que el reino se acerca, lo que introduce lambién a lo que es el reino. La razón fundamental por la cual se describe a Jesús haciendo milagros es la compasión y la misericordia hacia los débiles y los oprimidos. Repetidas veces se dice que Jesús sintió compasión y misericordia ante el dolor de los débiles. "Vio mucha gente y compadecido de ellos curó a sus enfermos" (Mt. 14,14). Se dice que sintió 
compasión por un leproso (Mc. 1,41), por dos ciegos (Mt. 20,34), por quienes no tenían que comer (Mc. 6.2; Mt. 15,32), por quienes estaban como ovejas sin pastor (Mc. 6,34; Mt. 9,36), por la viuda cuyo hijo acababa de morir (Lc. 7,13). Esa misericordia es la que aparece también en las narraciones de milagros. Al menos en cuatro ocasiones Jesús cura tras la pelición: "Ten misericordia de mi" (Mt. 20, 29-34 y par; 15,21-28 y par; 17,14-29; Lc. 17,11-19).

Esta misericordia es la que explica los milagros de Jesús. Jesús aparece hondamente conmovido ante el dolor ajeno de los débiles. Reacciona ante ese dolor $y$, io que es más importante, reacciona con ultimidad. En la necesidad del débil hay algo último hacia lo que hay que reaccionar con ultimidad. Es importante notar que el verbo con que se describe la actitud de Jesús en los pasajes citados es esplaginizomai, proveniente del sustantivo esplaginon que significa vientre, entrañas, corazón. La misericordia expresada en los milagros de Jesús no es entonces una pura actitud de cumplir con algo prescrílo, no es una reacción motivada por algo ajeno al dolor mismo. Es la reacción -acción, por lo lanto-a una realidad que se ha interiorizado y que no deja en paz. Es por lo tanto una reacción primaria que, en último término, no tiene otra explicación -aunque después pueda ser declarada como virtud, como cumplimiento de la voluntad de Dios- más que en la realidad del dolor del débil. Con la misericordia estamos tocando algo último, no argumentable ulteriormente. Esto tan asl es que cuando Jesús quiere detinir al hombre cabal, lo define como el samaritano de la parábola "movido por la misericordia" (Lc. 10,33); y cuando quiere definir a Dios, el Padre del hijo pródigo, vuelve a repetir "movido por la misericordia" (Lc. 15,20). El mismo Jesús será definido en la Carta a los Hebreos como el hombre liel y el hombre de la misericordia. Que los signos del reino se realicen por misericordia significa que la razón - si es que se puede buscar razón a la gratuita iniciativa de Dios- de la cercanla del reino está en la misericordia de Dios, pero a la manera explicada: en el revolvérsele las entrañas a Dios ante el sưfrimiento de los débiles. Dios se acercará por esa razón y por esa sola razón.

De esta forma los milagros y los demás signos de Jesús algo concretan ya lo que es el reino de Dios para Jesús, más allá de las definiciones genéricas de salvación como amor o como vivir en plena apertura a Dios. Aunque son sólo signos, expresan que el reino de Dios es salvación de necesidades concrelas apremiantes; que es liberación. pues esas necesidades de las que hay que salvar son las producidas por elementos opresores; y que la razón del reino no está en nada ajeno y exterior a esas mismas necesidades.

A los signos que hizo Jesús los hemos llamado actividades al servicio del reino. Pero puede preguntarse si Jesús tuvo alguna actividad más globalizante, correlaliva a la tolalidad del reino y de la que se pudiese deducir lo que el rieno signilicaba en totalidad. Indudablemente Jesús no tuvo una teorla de la sociedad como tal. Sin embargo, tampoco puede decirse que Jesús nada ofrece sobre la dimensión de tolalidad del reino. Eso aparece en su visión del antirreino como tolalidad, de modo que sub specie contrarii algo también puede deducirse de lo que significaba el reino como totalidad, pues el antirreino no es sólo cosa distinta del reino, sino formalmente su contrario. En este sentido quizás podamos denominar praxis, análogamente, a ciertas actividades de Jesús, pues estaban destinadas a denunciar a la sociedad en su totalidad, a desenmascarar las causas del 
anlirreino y a transiormarb en el reino, aunque en ese punlo Jesús no olrece me. dios técnicos, sino la exigencia de conversión.

Que Jesús está convencido de la existencia del antirreino es claro. El mundo y la sociedad en que vivió no eran totalidades de acuerdo a la voluntad de su Padre, Dios; pero no sólo eso, eran estrictamente lo contrario. Eso es to que enseñan las conlroversias de Jesús en las cuales no se trata de pura casulstica - de resolver quaestiones disputalae secundarias, sino de la cuestión cenlral: quién es Dios, to cual en su sociedad religiosa significaba automáticamente la otra cuestión: cómo debe ser el mundo según Dios. En la controversia de las es. pigas arrancadas en sábado en un campo ajeno, por ejemplo, está en cuestión la primariedad de la vida con respecto al culto (dimensión religiosa de la controversia) y con respecto a la propiedad (dimensión social de la controversia). Jesús afirma que para Dios la vida tiene primariedad sobre cualquier otra cosa; que Dios es un Dios de vida, en lenguaje actual, y que la sociedad debe estar organizada alrededor de la vida. Lo que está detrás de las controversias es la alternaliva excluyente entre el Dios de la vida y otros dioses, entre reino y antirreino. Lo que en directo queda claro en la controversia es el rechazo que Jesús hace del anlirreino; pero, indirectamente, también se esclarece esle minimo: en nombre de Dios debe existir una sociedad alrededor de la vida.

Las denuncias de Jesús ponen de manifieslo su clara condena a los responsables del antirreino. Algunos anatemas pueden ir dirigidos a personas inviduales, pero en general los deslinatarios de las denuncias y analemas están formulados en plural. No es que Jesús, de nuevo, tuviera una teoría de clases sociales, pero sl presupone la existencia de grupos sociales que son responsables del antirreino. Ricos, fariseos, escribas, sacerdotes, gobernantes son denunciados y anatematizados. Contra ellos se dicen varias cosas: que son hipócritas, que vana es su existencia, que tendrá que dar cuenta en el dia del juicio, elc. Pero en (casi) todas las denuncias hay un elemento fundamental: son los causantes del antirreino, son opresores, producen victimas. En las abundanles denuncias contra esos responsables puede verse una denuncia contra la sociedad que ellos configuran como sociedad opresora, podrida en su ralz y no sólo en algunas de sus manif́estaciones. Es una sociedad en la que el poder a sus diversos niveles oprime a las mayorlas. Es el antirreino.

Jesús desenmascara el antirreino y sus ralces, desenmascara los mecanismos por los cuales el antirreino se puede hacer pasar por el reino. Desenmascara las tradiciones religiosas creadas por los hombres para poder anular la verdadera voluntad de Dios y manlener la opresión en nombre de Dios. Atirma por lo tanto que hay opresión, por qué la hay y cómo puede justificarse ideologizadamente tal situación de opresión. ${ }^{10}$

En resumen podemos decir que Jesús rechaza a esos grupos sociales y a la sociedad que configuran; a través de sus denuncias a los grupos responsables denuncia la contiguración de la sociedad. La sociedad que produce tantas victimas es el anlirreino y eso es lo que tiene que cambiar para que sea según la voluntad de Dios. De ahl se deduce un minimo, pero un minimo importante de lo que sea el reino. Este será contrario al antirreino; no habrá opresión de unos hacia a olros. En lenguaje actual y en el del AT el reino será un reino de justicia, un mundo organizado alrededor de la vida de quienes eran victimas, que superará 
las ralces que producen muerte y opresión. El "amor," como posible formulación de la sustancia del reino, tendrá que ser concretado desde la justicia. De otra forma no tendrian mucho sentido las denuncias y desenmascaramientos de Jesús.

Las denuncias y desenmascaramientos de Jesús, vistos como un todo, fungen como praxis, independientemente de la conciencia explicita que de ellos tuviera ál mismo. Es decir la finalidad de transofrmar la realidad social se verilica en el destino de Jesús, el cual, a su vez, esclarece lo que es el reino. Hoy casi nadie acepta que la muerte de Jesús en manos del poder polltico y como castigo por un delito politico fue un absurdo y trágico malentendido (Bultmann). Los dos juicios, más el religioso que el pollico, explican muy bien que sus adversarios sablan lo que haclan y por qué lo haclan. En el juicio religioso se acusa a Jesús de blaslemo, acusación formulada religiosamente. Pero junto a esta acusación, más bien redaccional, aparece la acusación fundamental: querer destruir el templo. En formulación religiosa se acusa a Jesús de querer subvertir radicalmente la sociedad, pues el templo era el slmbolo de la totalidad de la sociedad en lo religioso, económico, financiero y político. En el juicio politico se le acusa de acios de subversión concreta, y no son tenidos en cuenta por lalsos. Pero se le acusa, y por ello es condenado, de olrecer una alternativa distinla $-y$ en la formulación de los evangelios, excluyente- al imperio. Desde un punto de vista histórico es mucho más real la acusación que se le hace en el juicio religioso que en el polílico; pero la conclusión es la misma: Jesús representa objetivamente una amenaza a la sociedad conslituida, y por eso debe morir. Mons. Romero, en siluaciones tan parecidas a las de Jesús, lo explicaba con suma sencillez y claridad: se mata a quien estorba. $Y$ hay que añadir que mata aquel a quien se estorba. El agente último del asesinato de Jesús no hay que buscarlo en personas concrelas, sino en aquello a lo que estorbaba Jesús: su sociedad. En lenguaje sistemático podemos decir que Jesús, el "mediador" de Dios, fue asesinado por los mediadores de otros dioses porque la "mediación" de Dios, el reino de Dios, es una amenaza objetiva a otras mediaciones de otros dioses (la teocracia alrededor del templo, el imperio). El intento de acabar con Jesús fue una necesidad histórica y estruclural. Por ello, el hecho de que lo mataran es históricamente muy comprensible, aunque el que Dios lo permitiera es ya el misterio, el cual no vamos a abordar ahora?

Pero volvamos a lo que nos interesa: ¿qué dice el asesinalo de Jesús sobre el reino de Dios? De nuevo, algo minimo pero fundamental. No suele asesinarse a quien predica un reino exclusivamente transcendente, no suele asesinarse a quien predica un reino que fuese sólo una nueva relación interior con Dios o sólo "amor" o sólo "reconciliación" o sólo "conlianza en Dios." Estos pueden ser considerados como elementos acompañantes del mensaje del reino de Dios, pero ellos solos no explican la muerte de Jesús y por eso ellos solos no pueden ser lo central del reino, si es verdad que quien lo anunciaba lue asesinado por ello. Lo que Jesús entendió por reino de Dios fue algo que tenla que ver con lo histórico-social, no sólo con lo transcendente. Jesús lo anunció por razones religiosas, porque esa era la voluntad de Dios, pero su conlenido no era religioso en el sentido de ahistórico y asocial. Para recalcar este punto J.L. Segundo21 alirma que el reino de Dios anunciado por Jesús era una realidad política; no en oposición a lo religioso, sino en oposición a lo puramente trascendente o puramen- 
te individual. Y que lo verdaderamente religioso del reino de Dios no hace más que reforzar su dimensión polltica, pues conceptos como "reino" (y "pobres") "son tanto más decisivos politicamente cuando más son empujados, digámoslo así, por motivaciones religiosas. 22 Llámese al reino de Dios una realidad politica o histórico-social, lo importante es recalcar su dimensión histórica para Jesús. Para ól, el reino es "de Dios," es lo que ocurre en la hisloria cuando "Dios" reina; pero cuando Dios reina algo ocurre "en la historia" que la translorma y contigura de una determinada manera y en contra del antirreino.

Es necesario recordar que para Jesús el reino de Dios era una realidad histórica, lo cual no quita que sea también una realidad escalológica y teologal. $R$. Schnackenburg, por ejemplo, en su conocido libro sobre la materia, ${ }^{23}$ afirma taxativamente que "la salud anunciada y promelida con el reino de Dios es una dimensión puramente religiosa" (p. 63), de lo que saca además una consecuencia que nos ocupará más adelante: "por razón de su carácter puramente religioso el mensaje de Jesús acerca del reino de Dios tiene una trayectoria universal" (p. 67). ¿Cómo se puede llegar a hacer una alirmación tan simplista o, al menos, con tan poca dialéctica? Para defender su tesis Schnackenburg recuerda, con razón, que Jesús se distanció de expectativas teocrálicas y apocallpticas exaltadas y de mesianismos populares maravillosos. Pero de ahí no se deduce que el reino de Dios fuera puramente religioso. En nuestra oponión lal conclusión sólo es posible cuando no se considera el ministerio de Jesús, su actividad, su praxis y su destino, como algo que Jesús hace al servicio del reino.

Cuando esto se toma en serio, algo importante se puede decir del reino de Dios. El reino es salvación plural de necesidades concretas (enlermedades, hambre, posesión del maligno, indignidad y desesperación del pecador marginado); es liberación, pues esas necesidades son vistas como producto de causas históricas. Pero además, en su tolalidad, el reino es estricta oposición al antirreino histórico. En cuanto oposición, no es la extrapolación de las posibilidades presentes, y en cuanto oposición al antirreino historico, es algo que acaece en la historia, es una realidad histórico-social, polftica si se quiere. Nada de esto quita que el reino sea "de Dios;" al contrario. Jesús lo ve asl precisamente porque asl entiende a "su" Dios, y lo sirve con tal radicalidad - hasta llegar a ser asesinado- porque ésa cree ser la voluntad de Dios para este mundo.

La lercera via para determinar lo que es el reino de Dios es la via del destinatario, ya esbozada de alguna manera en la segunda. El recalcarla nos parece ser el aporte melodológico más especllico de la leologla de la liberación. El presupuesto fundamental es que contenido y destinatarios del reino se esclarecen mutuamente, mucho más cuando el destinatario no queda determinado de manera vaga e indiferenciada, sino concreta $y$, sobre todo, cuando se puede conocer la razón por la cual es destinatario del reino. Lo que hace el análisis del destinatario es concretar lo que sea la utopla y la salvación del reino; concretar, ciertamente, el antirreino, de tal manera que no se puede universalizar la salvación ni hacer intercambiable cualquier concepción de ella, precisamente porque el destinatario es concreto. 
La determinación exegética del destinatario del reino de Dios ya lo ha hecho la exégesis con anterioridad a la teologla de la liberación, aunque otras teologias sistemáticas no hayan sacado sus consecuencias. J. Jeremias, ${ }^{24}$ por ejemplo, ya afirmaba claramente en 1971 y con cierto matiz polémico quiénes eran los destinatarios del reino. Después de analizar el anuncio de Jesús y la cercanía del reino dice que con ello "no hemos descrito aún completamente su predicación de la 'basilea.' Antes al contrario, no hemos mencionado su rasgo esencial" (p. 133). Este consiste en el destinatario que son los pobres. Con gran radicalidad, dice: "el reino pertenece únicamente a los pabres... La primera bienaventuranza: la salvación está destinada únicamente a los mendigos y pecadores" (p. 142; subrayados en el original). No se puede hablar con más claridad. El mismo autor delermina lo que son esos pobres mentados como destinatarios del reino. Son los menlados en la primera bienaventuranza de Lc. 6,20. y aquellos a quienes se les predica la buena noticia en Mt. 11,5, y Lc. 7,23. Jeremias ${ }^{2}$ Irata de sistematizar el significado de pobres en una doble Ilnea: los agobiados por el peso de la vida (carácter absoluto de la pobreza material, socioeconómica diríamos) y los despreciados y marginados por la sociedad (carácler relacional de la pobreza, marginación sociológica). Aunque no sea lácil subsumir en un concepto univoco ambos significados, es obvio que pobres significa aqui una realidad histórica, aquellos para quienes vivir es una dura carga por razones históricas, económicas y sociales. En cualquier caso, los pobres, en cuanto destinatarios primarios del reino no lo son por lo que ocurra en su interioridad y cierlamente no lo son porque simplemente son seres humanos, limitados por lo tanto.

La leologla de la liberación toma muy en serio esta delerminación exegética del destinalario y sistemaliza la realidad de los pobres en base a los datos evangélicos. ${ }^{26}$ Pobres son una realidad económica y social: aquellos para quienes vivir es una dura carga por la dílicultad de vivir y por la marginación. Pobres son una realidad colectiva: pueblos pobres o pobres en cuanto pueblo. Pobres son una realidad historica: existen no principalmente por razones naturales, sino históricas, por causa de la injusticia. Pobres son una realidad dialéctica; existen pobres porque hay ricos y a la inversa. Pobres son una realidad politica: en su misma realidad poseen al menos un potencial conflictivo y Iransformador para la sociedad. Esta sistematización de la realidad de los pobres no se deduce, sobre, todo en el último punlo, inmediatamente de los datos evangélicos, pero recoge rasgos fundamentales, y la olrecemos para que la realidad de los pobres tenga entidad concreta y no se la difumine, como es tan frecuente. En cualquier caso, to que le interesa a la teologla de la liberación y lo que propone metodológicamente es tomar en serio que "estos" pobres del evangelio son los destinatarios del reino de Dios y que desde "eslos" pobres se puede concretar lo que sea el reino de Dios. Estas alirmaciones, que parecen tener una Kogica aplastante, no suelen ser, sin embargo, aceptadas, o se aceplan sin sacar sus consecuencias. Ello es comprensible porque de esta manera se alirma una parcialidad de Dios que, hoy como en el tiempo de Jesús, es escandalosa. La predicación de la buena noticia a los pobres, por serlo, produce escándalo (ctr. Mt. 11,6; Lc. 7,23). J. L. Segundo, después de un largo análisis, recalca esa parcialidad: "el reino de Dios no es anunciado a todos. No es proclamado a todos... El reino está destinado a ciertos grupos, es de ellos, les pertence. Sólo para ellos será causa de alegrla. Y, de 
acuerdo con Jesús, la línea divisoria entre la alegrla y la tristeza que habrá de producir el reino pasa entre pobres y ricos" (p. 132). Y da la razón de esa parcialidad, la cual suele causar mayor escándalo. "El reino viene para cambiar la situación de los pobres y ponerle fin. Que los pobres posean el reino de Dios, de acuerdo con la primera bienaventuranza, no es mérito de ellos, ni menos aún la consecuencia de un valor que tendría la pobreza. La razón es la opuesta: lo inhumano de su situación de pobres... Si los pobres estuviesen todavla sujetos a condiciones (morales y religiosas) para gozar del reino de Dios que llega, caerlan las bienaventuranzas originales... No se podrla decir que de ellos es el reino. $Y$ que es de ellos precisamente porque su siluación infrahumana los hace sufrir" (pp. 160, 209).

Si se toma en serio que los pobres son el destinatario del reino de Dios y que lo son simplemenle por ser pobres dos consecuencias sumamente imporlantes se deben sacar. La primera, obvia, es sobre el contenido del reino. Los pobres definen el reino de Dios por lo que son, concrelan la utopla que suele formularse, en parte por necesidad lógica, pero en su mayor parte por no querer concretarla, en forma abstracta; en el fondo para que no sólo los pobres, sino también "otros" y en último lérmino "todos" puedan ser el destinatario del reino. Al lormular esa concreción no es tácil elegir un solo término, pues como antes decíamos las necesidades - de los pobres, añadimos ahora- son plurales. Pero para formular el fin de su desventuras, siguen siendo significativos términos como la "vida," la "juslicia," la "liberación." Cuál sea la mejor lormulación del reino de Dios en el londo es cosa a lo cual sólo los mismos pobres pueden contestar, pues de ellos es el rieno y ellos conocen aquello de lo que el reino los líbera. Pero lo importante es que, sea cual fuere la formulación, los pobres concretan el contenido del reino como superación de la pobreza. Quizás pueda decirse simplemente que el reino de Dios es un mundo, una sociedad, que posibilita la vida de los pobres y su dignidad.

La segunda cosa importante que concrela el destinatario es que el reino es precisamente "de Dios;" es decir, su dimensión transcendente. Esta atirmación puede exlrañar, pues determinar que los pobres, tal como se los ha descrito, sean los deslinalarios del reino, suele originar la acusación de reduccionismo, economicismo, sociologismo, elc. Y puede extrañar también porque el mencionar lo transcendente nos estaría trasladando aulomálicamente a un mundo atemporal y amaterial. Se sigue teniendo la tendencia no sólo a distinguir, sino a oponer transcendencia e historia. Sin embargo, lo transcendente del reino de Dios debiera analizarse en un primer momento, al menos, en lo que tiene "de Dios," sea cual luere la manileslación de ese ser "de Dios."

En nuestra opinión, el hecho de que el reino sea de los pobres es una forma muy eficaz de expresar que el reino es "de Dios;" y ello tanto por lo que toca a la formalidad de Dios en cuanto misterio como por lo que toca al contenido último de ese misterio. Por lo que toca a lo primero, los pobres son destinatarios del reino no por alguna cualidad moral o religiosa en ellos ni porque la pobreza posibilite - aunque de hecho la posibilita — una mayor apertura a Dios. La razón es simplemente que asf es Dios. Ese ser asf de Dios no es lo pensado ni lo pensable (además de que para los adversarios de los pobres no sea ni lo querido ni to querible), es la manítestación de su realidad que, al menos desde un punlo de 
vista hisı́rico va más allá - transciende - las expectativas de la razón natural y. ciertamente, de la razón pecaminosa. Toda la vida de Jesús muestra cuánlo transciende a la idea convencional de Dios ese asl de Dios. La parcialidad del reino hacia los pobres causa escándalo y conflicto. $Y$ si en las bienaventuranzas Jesús anuncia a los pobres que el rieno de Dios es de ellos, en las parábolas tiene que defender constantemente anle sus adversarios esa parcialidad de Dios. -Dios no es como ustedes lo piensan, sino todo lo contrario," tiene que decir constantemente Jesús. No puede propiamente argumentar por qué es Dios así, sólo lo puede afirmar con la esperanza de que acepten a un Dios nuevo, al Dios que abraza al pecador, que paga lo mismo al que llega a trabajar a última hora, que se desvive por una sola oveja descarriada.

La "novedad" e "impensabilidad" de que los pobres sean destinatarios del reino se convierte en mediación histórica de la novedad e impensabilidad de Dios, de su misterio, de su transcendencia con respecto a imágenes humanas de Dios. Aceplar que el deslinalario del reino son los pobres es una forma eficaz de dejar a Dios ser Dios, de dejar que él se muestre como él es y como él quiere mostrarse.

La realidad transcendente de Dios podrá ser analizada desde otras perspectivas, desde su función suprahistórica en el origen y en el futuro, en la creación y en la pleniticación final. Pero la transcendencia de Dios puede ser analizada también desde su mostrarse asf y no de otra manera. En el fondo no otra cosa hizo Pablo al proponer la cruz como la sabiduría de Dios, obviamente locura y escándalo, pero a través de la cual Dios se manilestaba como Dios. Algo semejante ocurre al afirmar que el reino de Dios es de los pobres por ser pobres y sólo por ser pobres. A través de ello Dios se muestra como Dios, como el mislerio inmanipulable.

Pero también el destinatario ayuda a concretar el contenido del misterio de Dios. El NT dice con radicalidad que Dios es amor; pero el destinatario del reino lo concreta en forma de amor al débil, en forma de ternura hacia el débil y en forma de delensa del débil. Desde la flagrante inhumanidad a la que eslán sometidos los pobres se manifiesta la humanidad de Dios en forma de ternura, abajamiento amoroso, alegrla cuando el pobre y el pecador se dejan acoger por Dios. Desde los destinarios del reino se conoce no sólo que asf es Dios, sino que asl es Dios, tan bueno.

Los pobres como destinatarios del reino tienen, pues la capacidad de concretar el contenido hisiórico de ese reino. pero también la capacidad de hacer conocer mejor al Dios del reino. Desde ellos hay que dejar que Dios se muestre como es, sin que se pueda determinar de antemano cuál deba ser su revelación o cuál deba ser una plausible revelación; hay que dejarle libertad para que se revele como él quiere y no como lo desean los que se tienen por juslos y hombres de bien; hay que dejarlo que sea buena noticia como él quiere, y también —para espanto de muchos - que sea mala noticia; hay que dejarlo ser parcial, tal como se ha mostrado a lo largo de todo el AT y en Jesús, en definitiva, hay que dejarlo ser Dios y dejarlo que manifieste su amor como él lo decide: acercándose salvificamente a los que no son amados, sino oprimidos y despreciados en este mundo. Aunque también de otras formas habrá que abordar la realidad de Dios según el AT y el NT, no es pequeña ayuda la que proporciona el considerar a los pobres como los destinatarios del reino. Garantizan, al menos, la necesaria sorpre- 
sa para verilicar que se trata realmente de la revelación de Dios y exigen una pre-comprensión, que es además conversión, para poder estar abiertos y llegar a captar a ese Dios que asl se maniliesta.

Desde el servicio de Jesús al reino y desde sus destinatarios creemos, pues, que se puede concretar lo que fue el reino de Dios para Jesús. Sigue siendo utopia y por lo tanto, indefinible; pero, después de lo dicho, puede decirse que es la utopía de los pobres, el lin de sus desventuras, la liberación de sus esclavitudes, la posibilidad de vivir y vivir con dignidad. $Y$ también desde ahí puede concretarse mejor que el reino es "de Dios:" el Dios del reino es un Dios que desea la vida de los pobres y los libera del antirreino.

\section{El concepto slslematico del relno de Dlos}

La delerminación evangélica del reino de Dios es sumamente importante para la fe; pero por sl misma no olrece un conceplo sistemático del reino para la aclualidad. La leologla de la liberación que, a dilerencia de olras, mantiene la centralidad del reino, considera que el conceplo sistemálico del reino debe basarse en y recoger lo esencial del conceplo evangélico; eslo es necesario pero no suliciente. "El evangelio invita a la lantasía creadora a elaborar ideologías nacidas no de una magnitud a priori, sino del análisis y de los desaflos de una situación, en función de un proyecto liberador. Ante esto, el cristiano en su fe, no debe lemer asumir una decisión concreta con los riesgos del fracaso que implica, decisión que puede ser la venida históricamente mediatizada del reino. Por ello puede, dia tras dia, suplicar ardientemente: 'Venga a nosotros tu reino.' Ni la le ni la Iglesias saben de antemano cuál será la configuración concreta de tal decisión."27

Esta cita de L. Boff prohibe una lormulación absoluta del reino, recalca la necesidad (y los riesgos) de historizarlo hoy. Pero exige que haya alguna noción de lo que el reino puede signilicar hoy, algún horizonte desde el cual la respuesla a los desafios actuales pueda ser comprendida como realización, siempre provisional, del reino.

\subsection{La reallrmación actual del reino de Dlos}

Primero hay que conslatar que la leología de la liberación, con los riesgos y provisionalidad que ello conlleva, reafirma la necesidad de mantener el reino de Dios como conceplo central hoy. Las razones especílicas ya las vimos en la primera parte de este trabajo. Lo que hay que esclarecer es en qué sentido lo mantiene cuando olras teologlas lo abandonan como conceplo central teológico. Para entender lo que queremos decir podemos recordar la conocida cuestión por el cuándo de la venida del reino, cuya respuesta depende en el fondo de lo que se entienda por reino. Como es sabido, las soluciones exegéticas a la pregunta por el cuándo de la venida del reino son variadas. Según la escatología consecuente el reino será realidad sólo al final de los tiempos (A. Schweitzer); según la escalología realizada el reino ya se hizo realidad en la persona y actividad de Jesús (Ch.Dodd). Según la conocida tesis de Cullmann con la venida de Jesús ya ha comenzado el tin de los tiempos, pues el Maligno y el pecado ya han sido vencidos en principio, aunque sólo al final se develará la plenitud de Cristo; es la lesis 
del ya pero todavla no. En la teología sistemática se dice que la venida del reino puede considerarse "como algo cumplido provisionalmente con la propia resurrección de Jesús," pues "la resurrección universal de los muertos" debe ser comprendida "como la entrada en el reino de Dios" (Pannenberg). ${ }^{28}$ Bultmann abandona loda referencia al reino y afirma que lo último acaece en la historia siempre que se acoge el kerygma.29

La pregunta por el cuándo se responde, en último término, según se entienda lo que es el reino y esa comprensión del reino es lo que hace que se lo mantenga o abandone como lo cenlral para la teología. Para comprender en qué sentido la teología de la liberación sigue haciendo de él lo central hagamos dos aclaraciones previas.

La primera consiste en distinguir entre mediador y mediación de la volunlad de Dios. Según la economía salvífica tal como se ha realizado. Dios tiene siempre un mediador, un enviado, una persona que anuncia e inicia con signos lo que sea su voluntad para esle mundo y cuál deba ser la dirección que debe tomar el mundo para llegar a ser según su voluntad. En este sentido debe decirse que ya ha aparecido, que ya es realidad el mediador escatológico. Y en esle sentido también, pero sólo en ese sentido, son verdaderas las bellas palabras que nombran a Crislo la autobasilea de Dios, el reino de Dios en persona. Esto, por otra parte, no es más que una relormulación, ahora en el lenguaje de reino de Dios, de lo que es el núcleo de la fe cristológica: Crislo es el delinitivo mediador. Pero, por olra parte, la volunlad de Dios no es simplemente que aparezca en la historia un mediador, sino que en la historia se realice su voluntad para el mundo. A la realización de esa voluntad es a lo que llamamos mediación; en el lenguaje de los evangelios, el reino de Dios. Mediador y mediación eslán por lo tanto intrinsecamente relacionados, pero no son lo mismo.

La segunda cosa es distinguir entre "signos" y "realidad" del reino. La presencia de los signos es sumamente importante para explicilar simbólicamente la realidad del reino y desencadenar una esperanza sobre su posibilidad, de que se acerca. Pero, de nuevo, esos signos no son adecuadamente la realidad del reino. Las curaciones no hacen desaparecer la entermedad, ni la multiplicación de los panes el hambre, ni la expulsión de demonios el poder omnipermeante del Maligno, ni la acogida a los pecadores la marginación y el desprecio social.

¿En qué sentido puede decirse, entonces, que el reino es o no realidad? ¿Con qué criterios previos se constata y se mide la realidad del reino? La leología de la liberación afirma que el reino es realidad al nivel del mediador y que no hay que esperar otro mediador escalológico; afirma que es realidad a nivel de signos siempre que éslos acaecen en la historia. Pero recalca que no es una realidad al nivel de mediación, como en otro lenguaje lo recalcaba Pablo: Dios no es todavia todo en todos (1Cor. 15,28). El ya pero todavla no de Cullmann puede lungir como respuesta, pero entendiéndola bien. Es un ya definnitivo por lo que toca al mediador, aunque en la historia puedan y tengan que seguir surgiendo mediadores - medidos ahora por Jesús-; es un ya en la historia siempre que acaezcan los signos del reino. Pero es un todavía no - en la realidad del tercer mundo habrla que decir "ciertamente no-- por lo que toca a la mediación, a la realización de la voluntad de Dios para esle mundo. 
Lo que la teología de la liberación afirma entonces es to siguiente. En primer lugar, que no ha llegado el reino de Dios al nivel de mediación y que, sin embargo, sigue siendo la voluntad de Dios que llegue a este mundo. Del no haber llegado no saca la conclusión de olras teologlas que lo ignoran y se concentran en lo que sí ha llegado: el mediador. El que no haya llegado ofrece una diticultad intrinseca para su determinación, pero la teología de la liberación afirma que hay que seguir buscando hoy su delerminación. En segundo lugar, existe una continuidad y una discontinuidad entre el concepto sistemático y evangélico de reino de Dios. Lo segundo es obvio, pues se trala de cuál sea la voluntad de Dios hoy para el mundo real actual; de ello deduce la conocida exigencia de mediaciones analíticas para determinar el reino. Lo primero es obvio, pero desde la fe. La leologla de la liberación acepta totalmente que el mediador sl ha llegado y que, por lo tanto, en su visión del reino, en su actividad en favor del reino y en su determinación de los destinalarios del reino hay algo esencial y permanente, que deberá ser concretado, pero no ignorado; algo que deberá dirigir la delerminación del reino de Dios. Por simple que parezca el decirlo, la teología de la liberación acepla que en la vida real de Jesús, no sólo en lo acaecido en él en la resurrección, apareció con ultimidad la voluntad de Dios para este mundo y que ésta no ha sido revocada en la historia posterior.

\subsection{Presupueslos para la determinación del relno de Dlos}

Lo dicho hasta aqul muestra que la teología de la liberación hace una opción teológica en lavor del reino de Dios. Opción juslílicada o al menos justiticable y por ello razonable desde la revelación; opción necesaria y urgente desde la sítuación del tercer mundo; opción que puede apoyarse en muchos documentos eclesiales acluales. Pero en el fondo es una opción, una forma concreta y última de captar y formular la te cristiana.

Pero detrás de esa opción en la formulación de la le existen presupuesios históricos, existenciales, necesarios para comprender por qué tiene sentido la opción teológica fundamental en favor del reino de Dios y por qué se concrela ésla de la forma que luego veremos. Veamos a nuestro entender cuáles son esos presupuestos.

El presupuesto fundamental consiste en establecer el primado de la realidad de los pobres; en palabras actuales, de hacer la opción por los pobres. Desde ese primado se tiene también la expectativa -lógicamenle presupuesta, pero relorzada con su realización- de que la misma realidad y la revelación de Dios se harán más asequibles y transparentes.

Este presupuesto en sl mismo es una opción; no puede argüirse en su favor o en su contra en último término. J. Luis Segundo lo ha expresado con toda radicalidad para explicar su propia teologia en el punto concreto del presupuesto necesario para la lectura del evangelio. La opción por los pobres, afirma, "no es un tema de la teología de la liberación, sino la premisa epistemológica para inlerpretar la palabra de Dios. ${ }^{30}$ Enlatiza el aulor que ese presupuesto es realmenle anterior a la lectura del lexto bíblico, que ni siquiera el texto fuerza a ese presupuesto - aunque si exija algún presupuesto, alguna precomprensión一, que el presupuesio es, por ello, en último lérmino, una apuesla. 
Se puede discutir, como concede el autor, 31 que, en el caso concreto del acercarniento al texto evangélico, la opción por los pobres sea pura opción, puro presupuesto, o si el texto mismo induce a ella y la exige. Pero sea cual fuere la respuesta a esta pregunta, lo que queda claro en la teologia de la liberación y en todas sus variedades es que la opción por los pobres - como sea que se llegue a ella- es necesaria para leer el evangelio y, más aún, para leer adecuadamente la realidad. Recuérdese que la opción por los pobres no es patrimonio de crislianos y creyentes, sino de muchos olros seres humanos.

Lo importante es que la opción por los pobres no es un puro contenido evangélico o socio-hislórico, no es sólo una exigencia élica, no es por supuesto sólo algo que hay que realizar porque asl lo exigen documentos eclesiásticos de modo que, si no lo hubieran hecho, los cristianos no se verían obligados a ella. La opción por los pobres es algo más primigenio. Es una forma úllima de ver la realidad desde los pobres, y de ver en la liberación de los pobres el modo necesario de corresponder a la realidad.

Puede disculirse teóricamente cuál es la estructura inlerna de esa opción. La teologla de la liberación insiste en que liene la estructura de conversión, pues se hace en diferencia y en contra de olras opciones. La opción puede tener, por lo tanto, un componente ético, pero el nivel donde se realiza es más primario. Como afirma Pablo, los seres humanos tienden $\rightarrow$ y según Pablo, en lenguaje universalizante, lo hacen irremediablemente- a aprisionar la verdad. La conversión primaria es entonces dejar que la verdad sea, ver al mundo tal cual es, sin oprimirlo de antemano diclándole cómo tiene que aparecer. En esle sentido la opción por los pobres, en el lenguaje paulino, es considerada necesaria para desaprisionar la verdad del mundo, del mundo oprimido y del mundo opresor.

Puede discutirse, de nuevo, cómo se llega a hacer, existencialmente, la opción por los pobres. La teologla de la liberación insiste en que esa opción es posibilitada (o reforzada) desde los pobres. Cómo se logra optar "desde" los pobres es teóricamente discutible. Pero en cualquier caso hay que dejarse alectar radicalmenle por la realidad de los pobres, dejar que los pobres penetren con ultimidad y sin condiciones en uno mismo.

La opción por los pobres es enlonces una opción que se cree necesaria para captar la realidad hislórica y el evangelio, para responder y corresponder mejor a ambas cosas, para entrar en sintonla y alinidad con lo que dicen y con lo que exigen. Una vez realizada la opción puede crecer el convencimiento de que asl es, de que se capta más y mejor la historia y el evangelio. Se puede entonces teorizar la opción como el presupuesto hermenéulico necesario para comprender la realidad y el evangelio. Se puede entonces teologizar a los pobres, como lugar teológico, como mundo en que aparecen los signos de los tiempos. Se puede incluso aceptar como verdaderas las escandalosas palabras de Isalas: on los pobres, en el siervo crucificado, hay salvación y hay luz. Hay un relorzamiento mutuo, hisiórica y telógicamente, entre la opción por los pobres que ilumina la realidad y la realidad del pobre que convence de cuán alinada es la opción. Pero en definiliva, lo que recalca la leología de la liberación es el hecho mismo de la opción con anterioridad (lógica) al desarrollo de una teología de la liberación.

Esto signilica en concrelo que los pobres son los que guiarán la elaborción de lo que sea hoy el reino de Dios. Térica e hislóricamente el concepto del reino 
de Dios puede ser elaborado desde otros primados que no sean los pobres; puede ser elaborado desde las necesidades humanas universales, desde el ansia de liberlad, desde el deseo de supervivencia tras la muerte, desde la utopla del progreso conlinuo. De hecho, asi ocurre en varias teologias, y sus diferencias sistemáticas sobre el reino de Dios se explican, en último término, por los presupuestos con que se lee el texto evangélico y la realidad histórica actual. Cuando se hace la opción por los pobres, el conceplo sistemático de reino de Dios loma un rumbo preciso; es el reino de los pobres.

Desde la opción por los pobres se recogen también dos importanles planteamientos hermenéulicos necesarios para la comprensión del reino, a los cuales da soluciones novedosas. El primero es la cuestión de la esperanza. La leología moderna ha lenido el gran mérilo de redescubrir la dimensión de luturo al nivel metafísico, de esperanza al nivel antropológico y de promesa al nivel de la revelación. Pero además ha declarado que el reino es una realidad que por su naturaleza exige esperanza para poder ser caplado. Dicho en otras palabras, el reino es una realidad lal que si, por un imposible, los seres humanos no tuviesen esperanza, su contenido sería una contradicción lógica. La esperanza, por to lanto, es algo esencialmente necesario para comprender lo que es el reino. Pero, de nuevo, hay que preguntarse de qué esperanza se trata. La teologla de la liberación insiste en que se trata de la esperanza de los pobres. No niega, por supuesto, que el hombre sea el ser de la esperanza y que por ello pueda llegar a lorjar conceptos utópicos. Insiste, sin embargo, en que la esperanza, como dimensión antropológica, es sólo condición necesaria, pero no suliciente, para comprender el reino de Dios.

Análogamente a lo que se dice de la te, puede decirse que existe la spes quae y spes qua y ambas deben ser concretizadas desde los pobres para ofrecer acceso a la comprensión del reino. Aquello que se espera, la spes quae, es lo que esperan los pobres de este mundo: el fin de sus desventuras, la posibilidad de vida, la conliguración justa de un mundo que ahora les oprime. Los signos que esperan son los que les ofrecen ya algo de vida y les permiten esperar que la vida es posible.

Por lo que toca a la spes qua, al acto de esperar, los pobres esperan dentro de la dialéctica de signos realizados, fundanles de esperanzas, y de una realidad, masiva, cruel y estruclural, que activamente hace contra su esperanza. Esta dimensión del contra-esperanza le es inherente a la esperanza, y asl se recuerda desde Pablo hasta la teología moderna: la radical esperanza en la resurrección se realiza en contra de la muerte. Pero, de nuevo, los pobres concretan el "contra" de la esperanza: la actual situación de opresión, el antirreino. La esperanza del reino se realiza activamente como esperanza a pesar de y en contra del antirreino. La esperanza tiene siempre la estructura de acción victoriosa conlra lo que se le opone. Por ello es importante ver qué es aquello que se le opone. Para quienes la vida no tiene por qué ser ya objelo de esperanza, pues la poseen -aunque puedan cueslionar su sentido- el obstáculo a la esperanza suele ser la muerte final. Pero para quienes vivir sigue siendo objeto de esperanza, el obstáculo a su esperanza es el antirreino. No que los pobres (en 
América Latina cierlamente) no tengan una esperanza transcendente en la resurrección; para ellos tan milagro es vivir ahora como sobrevivir después. Lo que de contra hay en la esperanza lo ven no sólo en la muerte, sino en la imposibilidad de vida ya ahora. Por ello su esperanza es tan radical, cuando la lienen, ya ahora.

La leología de la liberación afirma entonces que para captar lo que es el reino de Dios no basta cualquier esperanza, sino la esperanza de los pobres; que hay que hacer propia, de alguna manera, su esperanza. Pero realizada ésta, también se comprende mejor sistemáticamenle lo que deba ser el reino de Dios; una promesa de vida en contra del antirreino.

La segunda cuestión es la de la praxis. La leologla moderna recalca la necesidad de una praxis cristiana, como la exige todo el NT. El problema no está, por lo tanto, en la necesidad de praxis para la vida cristiana, sino en relacionarla con el reino de Dios. De éste se recalca que es don graluito de Dios y que no puede lorzarse por la actividad humana. Por lo que toca a la hermenéutica, el reino de Dios serla una realidad que sl exige esperanza para ser caplado, pero que en sl mismo no exigirla una praxis.

La teología de la liberación no niega, sino que recalca la gratuidad del reino; pero exige una praxis, también cuando habla del reino. La razón evangélica está en que el mismo Jesús hizo muchas cosas en servicio del reino y en principio hizo a sus oyentes algún tipo de exigencias. Desde el primado del pobre la necesidad de la praxis en favor del reino es evidente. Que la praxis sea una necesidad no está, pues en discusión en la teologfa de la liberación. Lo que hay que analizar es el valor hermenéutico de la praxis, lo que ayuda a captar lo que es el reino de Dios, de lal manera que, a la inversa, sin praxis se conocerla peor y menos el reino de Dios; la praxis incluso ayuda a caplar su gratuidad.

En la práctica al servicio del reino se concretiza mejor y más elicazmente aquello que se espera. En el lenguaje de I. Ellacurla, ${ }^{32}$ en el encargarse de la realidad (dimensión práxica de la inleligencia) se profundiza en la realidad de la que hay que hacerse cargo. Empecemos negativamente. En el hacer la justicia aparece toda la hondura de la injusticia, en poner los signos denunciantes aparece con luerza la reacción de quienes captan el reino como mala noticia. En otras palabras, en la praxis, más que en el puro conceplo, es donde aparece con mayor radicalidad la existencia y realidad del anlirreino. Aparece no sólo que la realidad no es el reino, no sólo que el reino todavía no ha llegado, sino que el antirreino hace activamente contra el reino. Las innumerables persecuciones, asesinatos y martirios de los pobres que buscan liberación y de quienes los acompañan lo muesiran con loda claridad. La práclica, pues ayuda a comprender con una radicalidad no alcanzada sin ella que en verdad existe el antirreino y qué es éste en concreto, porque el antirreino no se revela contra cualquier actividad, sino contra algunas actividades especificas. Sub specie contrarii, de nuevo, se esclarece lo que es el reino hoy.

Positivamente, en la práctica se va esclareciendo lo que genera esperanza en los pobres. Muchas acciones béneticas pueden hacerse hacia ellos. Estas pueden generar alivio, pero no todas generan esperanza, aunque sean bienvenidas. En la práctica se decide qué signos, qué anuncio de la buena nueva, qué 
denuncia, qué planteamientos de nueva sociedad generan esperanza, y por ello apuntan en la dirección del reino; en la práctica se decide qué cosas celebran los pobres como signos del reino. Y en la práctica se decide también, por tanto, cuáles son los caminos del reino, entre el realismo de su viabilidad y la reserva de la utopla que mueve a buscar nuevos caminos.

La práctica es entonces no sólo una obvia exigencia ética, sino también principio hermenéutico de comprensión. Con anterioridad al hacer se sabe menos del reino de Dios que después de haber hecho algo por el reino. Desde la práclica se concretan y asl se captan lo que hoy sean signos, se descubren nuevos signos, se aprenden los caminos por los que hay que transitar. Este tipo de argumenlación es atIn, ciertamente, a una determinada teorla del conocimiento, pero se basa sobre todo en la rellexión de la teologla de la liberación sobre lo que ocurre en la realidad cuando se trabaja por el reino. La práctica ilumina lo que es el reino. Y podrla también preguntarse si el mismo Jesús no fue conligurando su anuncio inicial desde sus actividades y prácticas concretas y desde las reacciones a ellas por parle de los diversos grupos sociales.

Pero, además, para la teologla de la liberación la práctica no se opone a la gratuidad del reino, sino que la supone e incluso ayuda a esclarecerla. La teologla de la liberación acepta y valora la gratuidad del reino desde dos puntos de vista. En primer lugar confiesa que la consumación del reino es obra transcendente de Dios, como lo es su creación; la esperanza de la consumación última está puesta en Dios. La misma gratuidad que aparece en el provenir radicalmenle de Dios aparece también en el llegar definitivamente a Dios. La teología de la liberación para nada quiere poner en peligro la gratuidad del reino delinitivo de Dios, y sólo burdos intereses pueden querer hacerla decir la insensatez de que seres humanos puedan llegar a construir la pertecta utopla. En segundo lugar, la teologia de la liberación acepta y valora que la razón por la que Dios quiere acercarse en su reino es pura iniciativa de Dios, que no puede ni tiene por qué ser lorzada por acción humana alguna, simplemente - como se decla y recalcaba antes- porque Dios es asi.

Estos recordatorios debieran ser innecesarios, por obvios, ya que la teologla de la liberación es realmente cristiana y ortodoxa; pero no lo son porque se los cuestiona. Lo que quizás puede estar detrás de estos burdos cuestionamientos es el inlerés por ignorar o suavizar algo que sl recalca la teologla de la liberación: gratuidad para nada se opone a práctica; cristianamente hablando, más bien la exige. Lo que hay que analizar es cómo se entiende cristianamente la relación entre gratuidad y práctica, no la necesidad de ambas. Desde un punto de vista histórico hay que recordar que Jesús anuncia la graluidad del reino y por otra parte él mismo tiene una práctica y exige algo de los demás. Desde un punto de vista sistemático, en lenguaje del NT, hay que recordar que Dios nos ha amado "primero" de lo cual se deduce una práctica del amor histórico, el amor entre los hermanos. La graluidad para nada exime la práctica. Lo que hace la fe cristiana es proclamar dónde está la iniciativa y qué significa para la práctica que esté en Dios. Signitica que la práctica debe ser hecha no con hybris, sino con agradecimiento, que la primera práctica de Dios, su amor sin condiciones previas, muestra cómo hay que llevar a cabo la práctica histórica y cómo capacita para ella. El misterio de Dios es que "nos cré creadores" (Bergson); en el acto suyo 
más graluito nos dejó su impronta de ser, análogamente, como él, de ser con otros lo que él ha sido con nosotros, de hacer con otros lo que él ha hecho con nosotros, y de hacer con otros como él ha hecho con nosolros.

Hay que escuchar y anunciar que el advenimiento del reino de Dios es en úllimo término don gracioso de Dios; pero de ahl no se deduce la pasividad, sino la urgencia de anuncios históricos, el desvivirse por poner signos de su advenimiento, el proponer formas donde los hombres vivan de acuerdo a ese don último que sólo será realidad al linal. El que el reino nos sea anunciado y nos sea dado es lo que tiene que mover a llevar a cabo la práctica con un talante delerminado, la graluidad: "libres para amar," "liberados para liberar," dice G. Gutiérrez. ${ }^{33}$ El que el reino sea en delinitiva de Dios es lo que tiene que mover a una práctica sin hybris, más aún, a hacerla con conciencia de la limitación y aun del propio pecado ("hacer la revolución como un perdonado," sugiere J. I. González Faus). Pero el lalante de gratuidad y de humildad conligura la práctica, no la suprime.

En la misma práctica, además, se puede hacer la experiencia de gratuidad aunque esto sólo puede constarse cuando acaece; pero acaece. La gratuidad, el que todo tenga su origen en Dios, no tiene por qué ser expresado sólo con los ojos nuevos para ver lo que sin Dios no se podrla ver o con los oldos nuevos para oir lo que sin Dios no se podría oir. Puede también ser expresado como las manos nuevas para hacer lo que sin Dios no se podrla hacer. Muchos que se encuentran haciendo el reino formulan as l la gratuidad: algo $s \theta$ nos ha dado, y precisamente eso que se nos ha dado es poder hacer el reino, poner los signos que antes no se ponían, anunciar lo que antes no se anunciaba, correr riesgos que antes no se corrlan, permanecer en la persecución que antes se rehula. Ese antes expresa lo que es lo normal, lo que son históricamente las posibitidades humanas. Ahora, to que parecla imposible se ha hecho posible: trabajar decididamente por el reino. $Y$ eso es experimentando como don.

La teologla de la liberación propone, pues, la práctica del reino no sólo como una obvia exigencia ética, sino $\infty$ mo principio hermenéutico para conocerlo e incluso conocerlo en lo que tiene de don. Esa práctica y el asumir la esperanza de los pobres son concreciones de la opción por los pobres que capacitan hoy para la comprensión del reino de Dios.

\subsection{El concepto slstemátlco de relno de Dlos}

Después de estas rellexiones podemos contestar a la pregunta qué entiende la teologia de la liberación sistemálicamente por reino de Dios. Formalmente hablando entiende por reino de Dios una realidad hislórica que en sI misma tiene la virtualidad de abrirse y apuntar siempre a un "más." Materialmente hablando, recoge en el concepto de reino de Dios lo fundamental del concepto evangélico historizado desde los principios hermenéuticos expuestos. El reino de Dios es, entonces, un reino de vida; una realidad histórica - la vida justa de los pobres-y una realidad que en sí misma tiende al más, en definitiva, a la utopla.

En esta detinición debiera quedar claro, por el primado que se le da en el evangelio y en la opción, que los pobres son destinatarios primarios del reino. El que el contenido se detina como "vida" debe esclarecerse. Indudablemente lo.que está en juego no es el término en sl mismo, para el cual pudieran buscarse otros equivalentes. Se elige "vida" porque, creemos, recoge mejor lo histórico y lo utó- 
pico del reino de Dios. Se añade "justa" para indicar tanto el camino para conseguirla en presencia del antirreino como para expresar la condición de que sub. sista.

La teologla de la liberación insisle en la vida como el contenido histórico del reino porque pobreza, en el tercer mundo, significa cercanla a la muerte: po. bres son "los que mueren antes de tiempo" (G.Gutiérrez). Con "vida" se quiere afirmar que con el reino los pobres dejarán de serlo. La teologla de la liberación insiste en el sentido primario de la vida, sin precipitarse a analizar el "más" que toda vida lleva consigo. Paradbjicamente se orienta más hacia la protologla (idea. lizada) que hacia la escatologla; más hacia la creación que hacia la plenilicación. La vida no funge como un presupuesto que, una vez asegurado, lanzase a realizar lo verdaderamente humano y donde sólo entonces tuviese senlido hablar de reino de Dios. La vida en el tercer mundo no es lo presupuesto, sino lo que siempre hay que "poner"; es una finalidad en sl misma. Por decirlo desde lo negativo, el pecado primario del reino no es contra la escatologla, sino contra la creación.

La vida justa es lo que relaciona hoy el concepto sistemático con el con. cepto evangélico del rieno. Es la buena nolicia para millones de seres humanos; es lo que mueve a poner signos movidos por la misericordia ante los rostros de los pobres y lo que mueve a denunciar el anlirreino generalizado. Propiciar la vida es también lo que sigue hoy causando escándalo, conflicto, persecución y muerte. Todo ello hace que la buena noticia del reino pueda hoy lormularse cristianamente y con sentido como la vida de los pobres.

Pero también la vida es una realidad que, por su propia naturaleza, está siempre abierta al más; su concepto es dinámico y direccional apunla a un desdoblamiento de sl misma para realizarse a diversos niveles, con nuevas posibilidades y exigencias. La vida apunta a lo que en el concepto de reino de Dios hay siempre de "más."

En el reino de Dios tiene que haber pan, símbolo primero de la buena noticia hoy. Pero esa misma realidad del pan lleva consigo la pregunta por el cómo conseguirlo, con lo cual se exige algún tipo de actividad y de trabajo. Una vez que hay pan surge la exigencia de compartirlo - lo ético y lo comunitario-, surge la tentación a no compartirlo - el pecado-y la necesidad de celebrarlo por el gozo que el pan produce. El pan conseguido por unos es en sl mismo una pregunta por el pan de otros grupos, otras comunidades, por el pan de lodo un pueblo $-y$ surge la pregunta por la liberación. $Y$, entonces, conseguir pan para todo un pueblo signitica práctica, rélexión, ideologlas funcionales, riesgos, amenazas.

$Y$ puede surgir la exigencia de arriesgar hasta la propia vida para que el pan no se convierta en slmbolo de egolsmo, sino de amor. $Y$ el pan es más que pan, tiene algo de sacramental; y asi se celebra la fiesta del malz, y los que se juntan no solo comen pan, sino que cantan y recitan poemas, y el pan se va abriendo al arte y la cultura. Y nada de esto acaece mecánicamente, sino que en cada estadio de la realidad del pan aparece la necesidad del esplritu: esplritu de comunidad para compartir y celebrar, esplritu de valentla para luchar por él y de fortaleza para mantenerse en esa lucha; esplrílu de amor para aceplar que el trabajar por el pan de otros es lo más grande que puede hacer un ser humano. Y la buena noticia del pan puede llevar a agradecer al Dios que lo ha hecho o a la 
pregunta de por qué permite Dios que no haya pan abundante para todos; puede llevar a preguntarse quién es aquel que multiplicó panes para saciar el hambre y, sin embargo, lo mataron por ello; puede llevar a preguntarse si la Iglesia toma en serio el pan como buena noticia y cómo lo relaciona con su misión. Puede llevar a preguntarse también si hay algo más que pan, si hay un pan de la palabra, necesario y buena noticia incluso cuando no hay pan material; si es verdad que al final de la historia habrá pan para todos, si merece la pena caminar y trabajar en esta historia para que asi sea, aunque a veces la oscuridad lo permee todo; si la esperanza del pan para todos es en verdad más sabia que la resignación... La vida es siempre más y en el pan hay siempre más que pan. Pero hay que recalcar que la realidad del pan se desdobla on esta direoción cuando se trata no de cualquier pan -ol del lujo y el que propone la riqueza- sino el pan de los pobres.

Esta breve lenomenologla del más que hay en el pan, sea cual luere la lortuna de su descripción, sólo prelende mostrar cómo la vida misma se desdobla siempre en "más." Por ello la leologla de la liberación recalca el carácter histórico del reino - la vida - que en sl míisma lleva hacia el más; $y$, como no le pone limites a ese más, lleva a lo utópico. Esta es la razón última por qué la teologla de la liberación tiene que hablar de una liberación "integral;" no para equilibrar, por adición, liberación "material" con otras liberaciones más espirituales, sino porque en eso material primario que llamamos vida de los pobres está siempre el germen de un más de vida. En este sentido puede decirse que el reino de Dios es vida, vida abundante y la pleniticación de la vida.

La teologla de la liberación, por to tanto, recalca el aspecto histórico y utópico del reino. En ello no es especialmente novedosa, pero si lo es en el modo de relacionar ambas cosas en comparación a como lo hacen otras teologlas.

En primer lugar, insiste y defiende lo que de histórico hay en el reino de Dlos, tanto por obvias exigencias áticas como porque cree que desde ahl se plantea mejor y sin los habituales peligros alienantes lo que el reino tiene de utópico. Con ello quiere asegurar que la pleniticación linal del reino no haga ignorar o pasar a segundo plano la realización de la voluntad de Dios para los pobres. En las repetidas palabras de Mons. Romero, "es preciso defender to minimo que es el máximo don de Dios: la vida."

En segundo lugar, to utópico del reino es comprendido como gula de los caminos que se deben transitar en la historia y no sólo como relalivización de los ya transitados. A diferencia de otras teologlas, la de la liberación no enfatiza, aunque obviamente lo acepta, el carácter relativizador del reino utópico sobre todo lo que sea histórico. Conoce la "reserva escatológica" y sorprendería más bien que no la aceptase. La realidad de los pobres dice evidentemente que la historia actual no es el reino de Dios. Recordarlo en América Latina para evitar el peligro de adecuar la historia con la utopla del reino serla un sarcasmo. La teologla de la liberación no rechaza la lunción de la reserva escatológica, pero la interpreta de otra forma. La escalologla no sólo pone "reservas" a lo histórico, sino que to condena. $Y$, positivamente, no relativiza toda configuración histórica por igual, sino que las jerarquiza. Hay una talacia en insistir en que nada es el reino de Dios, como si la distancia entre éste y cualquier contiguración histórica fuese la misma por ser infinita. La teologla de la liberación sabe muy bien que utopla es aquello que por definición nunca se realiza en la historia (outopos); pero 
sabe también que hay topoi en la historia, y que en unos mejor que en otros se realiza la voluntad de Dios.

Por último la teologla de la liberación comprende lo utópico del reino de Dios no sólo como lo que acaecerá al final de la historia, sino como lo que ya se hace presente como fuerza atrayente en la historla. Esa fuerza no consiste, como en Pannenberg, en que, por no ser realidad, la utopla permite y exige vivir de una determinada manera y esl vivir ya como hombres salvados. Con toda la provisionalidad del caso, hay lormulaciones de la utopla que atraen y hacen que la historia dé más de sf: justicia, fraternidad, liberación o las conocidas palabras de Rutilio Grande: "una mesa común con manteles largos para todos, como esta Eucaristla. Cada uno con su taburete. Y que para todos llegue la mesa, el mantel y el conqué." La utopla es lo que atrae con fuerza, lo que moviliza, lo que una y otra vez mueve a que los seres humanos den lo mejor de sí mismos para realizar el reino. La teología de la liberación cree que la ulopla última está más allá de la historia, pero que desde ahora mueve a la historia.

\subsection{El carácter totallzante del relno de Dlos}

El reino de Dios, asl entendido, es central en la teologla de la liberación. Lo que hay que preguntarse, para terminar, es si y como el reino de Dios, como objeto leológico central, tiene la capacidad de organizar todos los contenidos de la teologla A continuación olrecemos, en apretado resumen, $\infty$ mo el reino de Dios se puede compaginar, organizándolos y enriquecíandolos, con los más importantes temas de la teologla, añadiendo que, aunque esta organización se realiza conceptualmente, creemos que se basa en la experiencia de muchos que creen, trabajan y sulten por el reino de Dios.

Por lo que toca a la teo-logla, en el conceplo de reino de Dios está incluido, por definición, Dios, y con la ultimidad que le es propia. Desde el reino de Dios aparece la ultimidad de la voluntad de Dios, su designio, su transcendencia; y también, su contenido como lo sumamente bueno: el amor y la ternura. A ese Dios le llama la teologla de la liberación el Dios de vida. Por la propia naturaleza del reino, Dios no aparece como un Dios celoso del bien de los hombres; más bien, su gloria consiste en la vida de los pobres. Pero sl es celoso de los otros ldolos, de los Idolos con quien está en estricta contradicción. Por ello el amor de Dios puede denominarse como justicia, el amor en contra de la muerte que propician otros dioses. Dios se hace el Dios de las victimas de este mundo y esa solidaridad llega hasta los extremos de la cruz, de modo que tiene sentido la mención de un Dios crucificado. Pero ese Dios, sigue siendo afirmado como el que - gratuita y definitlvamente- será capaz de sacar vida de donde no la hay, de hacer surgir un reino definitivo en medio del antirreino de la historia.

Puede preguntarse cuál es la relación entre el Dios del reino y el otro gran simbolo de expresar la realidad de Dios: abbe, Padre. Esta advocación de Jesús es también irrenunciable y por ello hay que preguntarse como se compagina con el Dios del reino. El que Dios sea Padre para Jesús y para el creyente de hoy se muestra en la conlianza que Jesús deposita en él por el convencimiento de que el Padre es bueno. De ahl que a la fe le competa el momento de conliar y apoyarse en Dios. Pero esa bondad de Dios, que posibilita llamarle Padre, es la que Jesús 
describe en sus parábolas precisamente cuando habla del amor de Dios, no en general, sino a los destinatarios del reino. Puede decirse, sistemáticamente, que la bondad de Dios que lieva a nombrarle abba, Padre, se expresa en el hecho mismo de ser el Dios de los débiles y, por ello, inequlvocamente el Dios bueno. $Y$, a la inversa, la razón, lógica, de que Jesús pueda anunciar la venida del reino a los pobres es su convicción de que asl es Dios, el Dios bueno, Padre. El reino de Dios, por lo tanto, no desvla de, sino que recalca la realidad de Dios tal como lo mencionó Jesús: Padre.

Por lo que toca a la cristo-logia, afirmar que Jesús es el anunciador y mediador escatológico del reino de Dios es ya una afirmación de fe cristológica en sentido estricto. Auque la fe en la divinidad de Jesús sólo llega a ser después de la resurrección, su esencial relación con el reino algo puede esclarecer la lógica por la cual se puede llegar a confesar su divinidad. No hay que despreciar el hecho mismo de que Jesús, en medio de la historia, se atreviese a proclamar cuál es el secreto último de la historia y su final: es verdad que lo último de la historia es salvación y que, además, eso se acerca. Su resurrección puede ser interprelada lambién como la confirmación de parte de Dios de la verdad de ese Jesús en cuanlo anunciador escatológico del reino. La argumentación creyente en favor de la divinidad de Cristo -como lo muestran las hondas rellexiones de los padres-, que si Cristo no fuese Dios no habría salvación definitiva, puede relormularse en lenguaje del reino: si Cristo no es Dios, vana es la esperanza de salvación que trae el reino.

Por lo que toca a la verdadera humanidad de Jesús, es evidente la relevancia de la relación de Jesús hacia el reino. Lo que esa relacionalidad constilutiva tiene de práctica histórica y de historicidad en la subjetividad de Jesús lo muestra como verdadero ser humano, sujeto a lo que hay de universal on to humano, pero presentando también en qué consiste el verdadero ser humano. El participar de la corriente esperanzadora de la humanidad que espera un reino, su pro-exislencia, su misericordia, su amor hasla el final, la lortaleza en manlenerse en las pruebas, externas e internas (tentaciones, crisis galilea, ignorancia), su esperanza contra esperanza lo muestran como ser humano y $\rightarrow$ según la contesión cristológica- como el verdadero ser humano.

El reino de Dios es, por lo tanto, también una realidad desde la cual se puede esclarecer la lógica de la confesión cristológica —una vez aceptada en la fo-; con la ventaja, sobre otras formas, de recalcar lo concrelo de ese ser humano que revela a Dios y lo concreto de ese Dios que se muestra en lo humano. Los peligros de que la le cristológica degenere en abstracción son menores; y la invitación-exigencia a recorrer el camino hlstórico de Jesús como modo de llegarlo a conocer y a confesarlo como el Crislo es más obvia desde el reino de Dios.

Por lo que loca a la eclesio-logia el reino de Dios ofrece el horizomte último de comprensión de la identidad y misión de la lglesia Le recuerda que ella no es el reino de Dios, sino su servidora por principio; y que sus realizaclones internas deben ser signo del reino en la historia. Le exige que su misión sea, como la de Jesús, buena noticia a los pobres, evangelización y denuncia, anuncio de la palabra y realización histórica de liberación. De esta forma puede hoy la lglesia ser "sacramento de salvación." 
El destinatario primario del reino, los pobres, le exigen una real encarnación en la historia de la pasión del mundo, con lo cual la lglesia resuelve en principio el difícil problema de estar en el mundo sin mundanizarse, es decir, sin dejarse regir por los valores mundanos con los cuales se oprime a los pobres; de ser mundanal, pero no mundana. Los pobres concretizan la realidad interna de la Iglesia como pueblo de Dios desde la igualdad fundamental de lo humano, pero desde la parcialidad de aquello humano por lo que Dios siente predilección y que, por su propia naluraleza, puede producir una te y una esperanza más evangélicas. La Iglesia tiene que organizarse en su interior poniendo su centro en la malerialidad de la pobreza de este mundo con el esplritu que puede surgir más espontáneamente desde ahl. En el lenguaje de Puebla, desde la evangelización que ofrecen los mismos pobres: en lenguaje sistemático, desde "los pobres con esplritu, "como indica I. Ellacurla. ${ }^{34}$

Esa Iglesia de los pobres es la que está en la historia real y crece en la historia; la que agradece cuando aparecen los signos del rieno, la que pide perdón cuando los anula; la que celebra los sacramentos y la palabra.

Terminemos con unas palabra sobre la espiritualidad ${ }^{35}$ que desencadena el reino de Dios, pues es algo que elabora positivamente la teologia de la liberación y que debe ser mencionado anle las acusaciones en conlrario. Esa espiritualidad es ante todo teologal porque debe enfrentarse con lo último. Exige elegir ante la ineludible alternativa de servir a Dios o servir a los Idolos. Es una espiritualidad que llama a recorrer los caminos de la vida y que dan vida en contra de los caminos de la muerte y que dan muerte. Toma muy en serio, por lo tanlo, la elección entre lo que verdaderamente es gracia y pecado. Desde el reino de Dios se esclarece con fuerza lo que es pecado y su analogatum princeps: dar muerte; y también lo que es gracia: dar vida. Se esclarece la dimensión histórica, social, estructural de ambas cosas, pero también la dimensión personal, pues por acción u omisión todo ser humano en su decisión personal está ante esa alternativa.

Es una espiritualidad cristológica, pues ve en el seguimienlo de Jesús el paradigma de loda espiritualidad; seguimiento que es práctica, misión, hacer el reino; pero seguimiento que debe ser hecho no mecánicamente, sino con espiritu y con el mismo espíritu que se hizo presente en la vida de Jesús y en las exigencias de Jesús, precisamenle cuando él sirve al reino y cuando él habla del reino: esplritu de misericordia, de limpieza de miras, de fortaleza, de empobrecimiento...

Es una espiritualidad, por último, que cree en la acción del Espíritu hoy en la historia para buscar y encontrar nuevos caminos históricos en la construcción del reino, para mantener la esperanza de que es verdad que el reino se acerca a pesar de las apariencias, para mantener, concrelizar y ahondar la fe en Dios. El que hoy pueda y lenga que hacer oración, ponerse delante de Dios, dejarse hablar por Dios y hablar a Dios, no es nada rutinario, sino algo que por su naturaleza confronta a quien trabaja por el reino y algo posibilitado por el Esplritu de Dios.

La teologfa de la liberación habla de la necesidad de la espiritualidad. La liberación, la práctica de la justicia, la construcción del reino es algo irrenunciable; pero esa decisión fundamental por la vida de los pobres tiene que eslar llena de esplritu. Ambas cosas se ven como necesarias y como mutuamente protenciadoras. La primariedad de la práctica de la liberación exige esplritu, pero posi- 
posibilita un determinado esplritu que no se consigue desde otros cauces; el esplritu con que hay que llenar la práctica de la liberación no hace desentenderse de ella, pero sana sus inevitables peligros y unilateralidades y aun la potencia. Para expresar esa mutua relación se habla de "contemplativo en la liberación" (L. Bofl), "contemplativo en la acción por la justicia" (1. Ellacuría). Se puede hablar de "santidad polftica," de unilicar fe y justicia, de conocer a Dios haciendo la juslicia... Las formulas son diversas, pero todas tienen algo fundamental en común: la construcción del reino de Dios exige un determinado espiritu, pero también lo posibilita; y por ello la teologla de la liberación tiene una espiritualidad.

Este apretado resumen sólo pretende ilustrar lo que la teologla de la liberación hace en su tolalidad; pero puede ser suticiente para mostrar que el reino de Dios no es sólo objeto central de la teologla, sino lo que puede organizar —en el tercer mundo mejor que otros — la totalidad de la teologla. Al elegir el reino de Dios como su objeto, la teologla de la liberación no pretende -ciertamente en su intención, pero tampoco en sus realizaciones objetivas- empequeñecer o reducir la totalidad de la teologla, sino todo to contrario; y en la realidad concreta del tercer mundo, le parece la mejor manera de polenciar la totalidad de la teologla. ${ }^{36}$

Lo que en delinitiva dice la teologla de la liberación es que en la historia -junto con otros seres humanos, y de ahl el ecumenismo radical que ofrece el concepto de reino de Dios- hay que construir el reino y que, desde la te, a través de esa construcción parcial nos encaminamos al delinitivo reino de Dios. Como el profeta Miqueas, la teologla de la liberación tiene claro lo que hay que hacer: "detender el derecho y amar la lealtad" — propiciar la vida de los pobres en la historia-; y como el proleta tiene la fe de lo que en último término significa esa práclica: "caminar humildemente con Dios en la historia." Lo primero exige poner siempre signos configuradores del reino, denunciar el antirreino y proponer lormas de vida más abundante para los pobres. Lo segundo exige la le en el sentido útimo de la historia, en el designio plenificante de Dios, simplemente la le en Dios tal como se manifestó en Jesús. Esa fe es la esperanza de que la historia será salvada por Dios. Y entonces sl, pero no antes, el reino de Dios se hace teológicamente intercambiable con la resurrección de los muertos o con el paulino "Dios todo en todos."

\section{NOTAS}

1. Teologla de la liberación, Perspectivas, Lima, 1971.

2. L Boff, Jesucristo y la liberación del hombre. Madrid. 1981; J. L. Segundo, El hombre de hoy ante Jesús de Nazaret, Madrid, 1982; Hugo Echegaray, La práctica de Jesús, Lima, 1901; J. Sobrino, Cristologla desde Amériea Latina, México, 1977; Jesús en America Latina, Sen Salvador, 1982; "Jesús de Nazaret," en Conceptos Fundamentales de Pastoral, Machid, 1983, pp. 480-513.

3. L Bolf, Eclesiogennesis, Santander, 1979; Iglesia, carisma y poder, Santander, 1984; I. Ellacurla, Conversión de la Iglesia al reino de Dios, Sentander, 1984; R. Muñoz, La Iglesia en el pueblo. Lima, 1983; A. Quiroz, Eclesiologia en la reología de la liberación, Salamanca, 1983; J. Sobrino, Resurreccion dela verdadera lglesia, Sandander, 1981.

4. Aporte de la teologla de la liberación a les religiones abrahámicas en la superación del individualismo y del positivismo," manuscrito de una ponencia que será presentada al Congreso de religiones abrahamicas, Cordoba, España, lebrero, 1987. 
5. Varios aspectos de esta interpretación de la resurrección los hemos desarrollado en Jesús en América Latina.

6. Marx y la Biblia, Salamanca, 1972, p. 315.

7. Art. cit. pp. 10-12.

8. Jesús, el Cristo, Salamanca, 1976, p. 86.

9. "Salvación en Jesucristo y proceso de liberación," en Concilium, 1974, 96 , p. 378; pero en la reflexión de $L$. Boff toma un papel muy importante la consideración de las otras dos vlas.

10. efr. op. cit.

11. Ctr. Fundamentos de cristologla, Salamanca, 1973. En un libro poslerior, Teologla y reino de Dios, Salamanca, 1974, aborda el tema del reino de Dios tomando algo más en consideración sus repercusiones sociales e históricas.

12. Ctr. Was ist der Mensch? Gütingen, 1962.

13. Jesus, An experiment in Christology, New York, 1979, p. 143.

14. Jesus und die Revolutionären seiner Zeil, Tübingen, 1970.

15. Carlos Escudero Freire, Devolver el evangelio a los pobres, Salamanca, 1978, p. 270.

16. G. Baena. "El sacerdocio de Cristo," Diakonia, 1983, 26.

17. Jesús, Madrid, 1983, p. 168.

18. Teologla del nuevo Testamento I, Salamanca, 1974. p. 115.

19. Véase la sugerente interpretación de J. L. Segundo, op. cit, $M /$, pp. 180-199., sobre las parábolas de Jesús como desenmascarantes y desideologizantes.

20. Cir. J. Sobrino, Jesús de Nazaret, p. 249ss; I. Ellacurla, "Por qué muere Jesús y por qué lo matan," Diakonla, 1978, pp. 65-75.

21. Clr. op. cit., pp. 127-132.

22. Ibid, p. 129.

23. Reino y reinado de Dios, Madrid, 1977.

24. Ch. op. cit.

25. En su interpretación de Lc. 6,20 el autor se refiere a la pobreza malerial de los seguidores de Jesús, la cual distingue de la de Mt. 5,3. Pero ensancha el concepto de pobre real en una sistrmatización de acuerdo a la linee de los profetas.

26. Cr. I. Ellacurla, "Pobres," en Conceptos fundamentales de pastoral, pp. 786-802.

27. L. Bofl, op. cit., p. 398.

28. Op. cit., p. 300.

29. El Nuevo Testamento anuncia a Jesucristo como el acontecimiento escatológico, como la acción de Dios en la cual ha puesto lin al mundo antiguo. En el anuncio, el acontecimiento escatológico se hace cada vez presente, y se hace cada vez más acontecimiento en la fe. Para el creyente el mundo antiguo ha llegado a su fin, es 'nueva creación en Cristo.' Pues precisamente por ello el mundo antiguo ha llegado a su fin para ell, en que su existencia como la del hombre viejo ha llegado a su lin, en que él se ha hecho alguien nuevo y libre," Geschichte und Eschalologie, Tubingen, 1964, p. 180.

30. La opción por los pobres, clave hermenéutica para leer el evangelio," Sal Terrae, junio de 1986, p. 476.

31. No estoy muy seguro de por dónde he empezado ese clreulo. No sé hasta qué punto, a luerza de leer el evangelio, me he dado cuenta de que el evangelio dice una cosa ... Une vez que se ha entrado en el clrculo hermenéutico con la precomprensión de que hemos hablado, evidentemente nos convencemos de que el evangelio dice eso," ibid, p. 482.

32. "Hacia una tundamentación filosofica del método teológico latinoamericano," ECA, 1975, 322-323, Pp. 418ss.

33. Ctr. su obra fundamental sobre espiritualidad Beber en su propio pozo, Lima, 1983.

34. Conversión de la lglesia al reino de Dios., pp. 129-151. 
35. Véase la obra citada de G. Gutiérrez y J. Sobrino, Liberación con espiritu, Santander, 1985.

36. No quiere decir esto que la teologla de la liberación haya deserrollado con la misma creatividad todos los temas de la teologla. Hemos mencionado los que parecen ser más importantes. Pero quedan pendientes muchas tareas de lo cual la misma teologla de la liberación es consciente. Entre otras, el problema de la inculturación. la toologla de la mujer, los aspectos personales y familiares de la vida cotidiana, ete. 


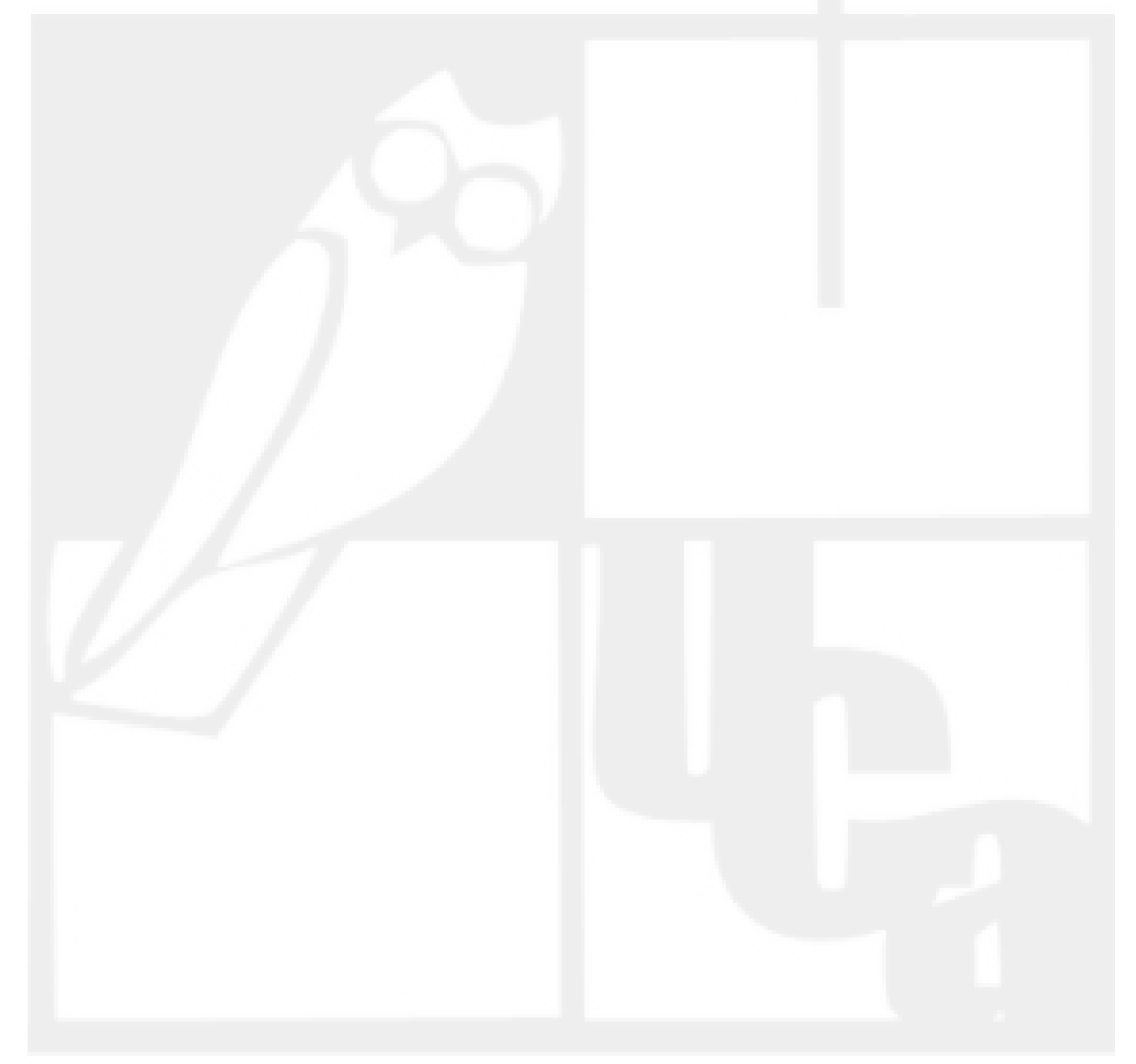

Digitalizado por Biblioteca "P. Florentino Idoate, S.J." Universidad Centroamericana José Simeón Cañas 